\title{
LEVEL II SCOUR ANALYSIS FOR BRIDGE 86 (VERNVT01420086) on STATE ROUTE 142, crossing BROAD BROOK, VERNON, VERMONT
}

U.S. Geological Survey Open-File Report 97-363

Prepared in cooperation with

VERMONT AGENCY OF TRANSPORTATION and FEDERAL HIGHWAY ADMINISTRATION 


\section{LEVEL II SCOUR ANALYSIS FOR BRIDGE 86 (VERNVT01420086) on STATE ROUTE 142, crossing BROAD BROOK, VERNON, VERMONT \\ By MICHAEL A. IVANOFF}

U.S. Geological Survey Open-File Report 97-363

Prepared in cooperation with

VERMONT AGENCY OF TRANSPORTATION

and

FEDERAL HIGHWAY ADMINISTRATION 


\title{
U.S. DEPARTMENT OF THE INTERIOR BRUCE BABBITT, Secretary
}

\author{
U.S. GEOLOGICAL SURVEY \\ Gordon P. Eaton, Director
}

For additional information write to:

District Chief

U.S. Geological Survey 361 Commerce Way

Pembroke, NH 03275-3718
Copies of this report may be purchased from:

U.S. Geological Survey

Branch of Information Services

Open-File Reports Unit

Box 25286

Denver, CO 80225-0286 


\section{CONTENTS}

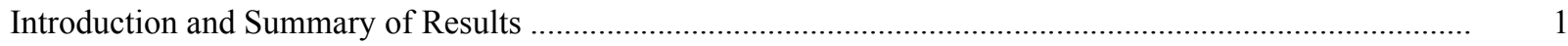

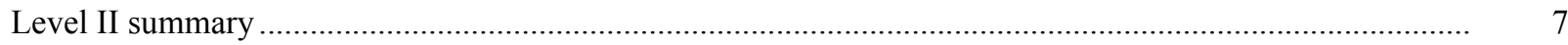

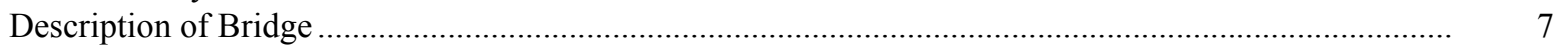

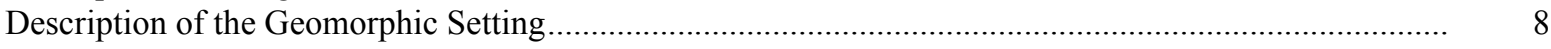

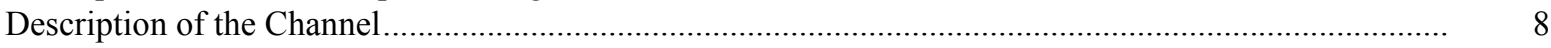

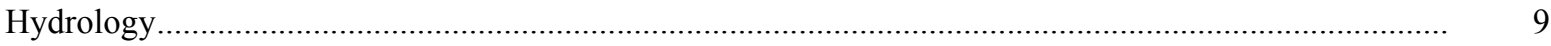

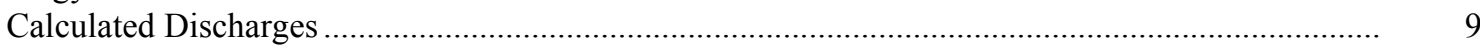

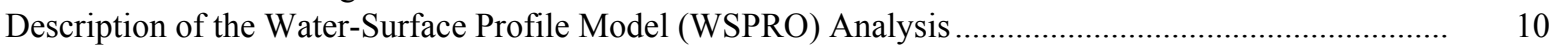

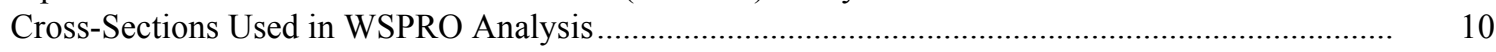

Data and Assumptions Used in WSPRO Model ...................................................................... 11

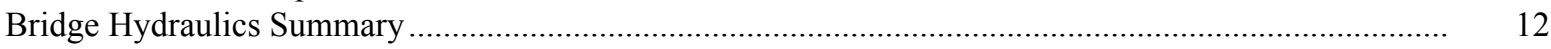

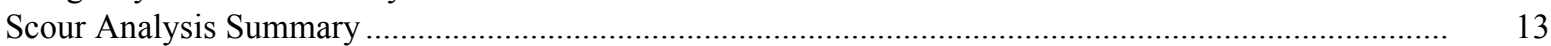

Special Conditions or Assumptions Made in Scour Analysis ...................................................... 13

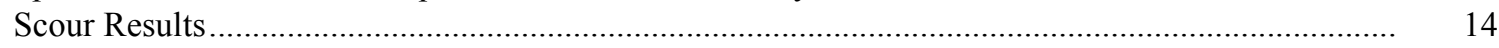

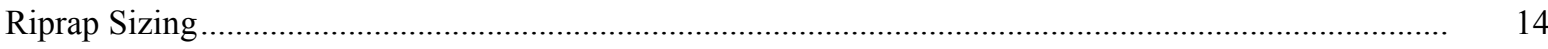

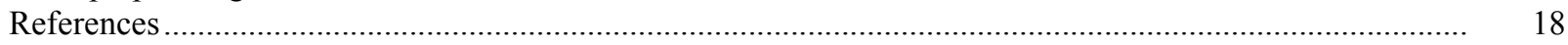

Appendixes:

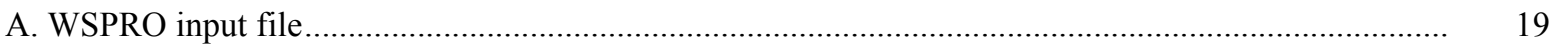

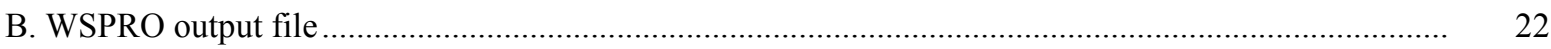

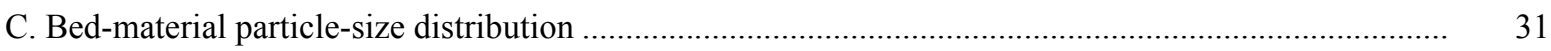

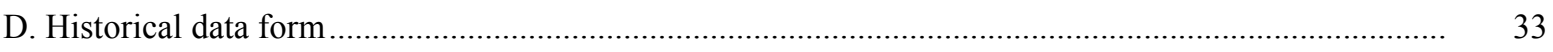

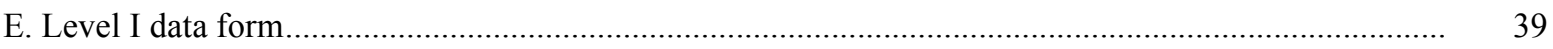

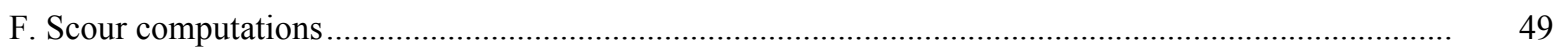

\section{FIGURES}

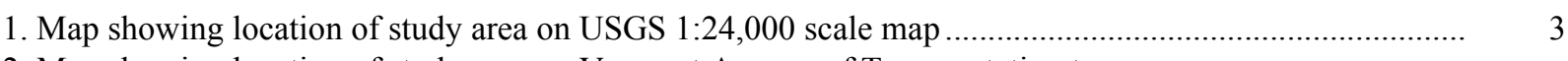

2. Map showing location of study area on Vermont Agency of Transportation town
highway map

3. Structure VERNVT01420086 viewed from upstream (August 14, 1996) .............................................. 5

4. Downstream channel viewed from structure VERNVT01420086 (August 14, 1996)............................ 5

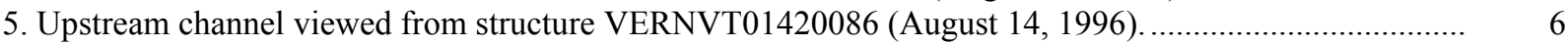

6. Structure VERNVT01420086 viewed from downstream (August 14, 1996)........................................ 6

7. Water-surface profiles for the 100- and 500-year discharges at structure

VERNVT01420086 on State Route 142, crossing Broad Brook,

Vernon, Vermont.

8. Scour elevations for the 100- and 500-year discharges at structure

VERNVT01420086 on State Route 142, crossing Broad Brook,

Vernon, Vermont.

\section{TABLES}

1. Remaining footing/pile depth at abutments for the 100-year discharge at structure

VERNVT01420086 on State Route 142, crossing Broad Brook,

Vernon, Vermont

2. Remaining footing/pile depth at abutments for the 500-year discharge at structure

VERNVT01420086 on State Route 142, crossing Broad Brook,

Vernon, Vermont 


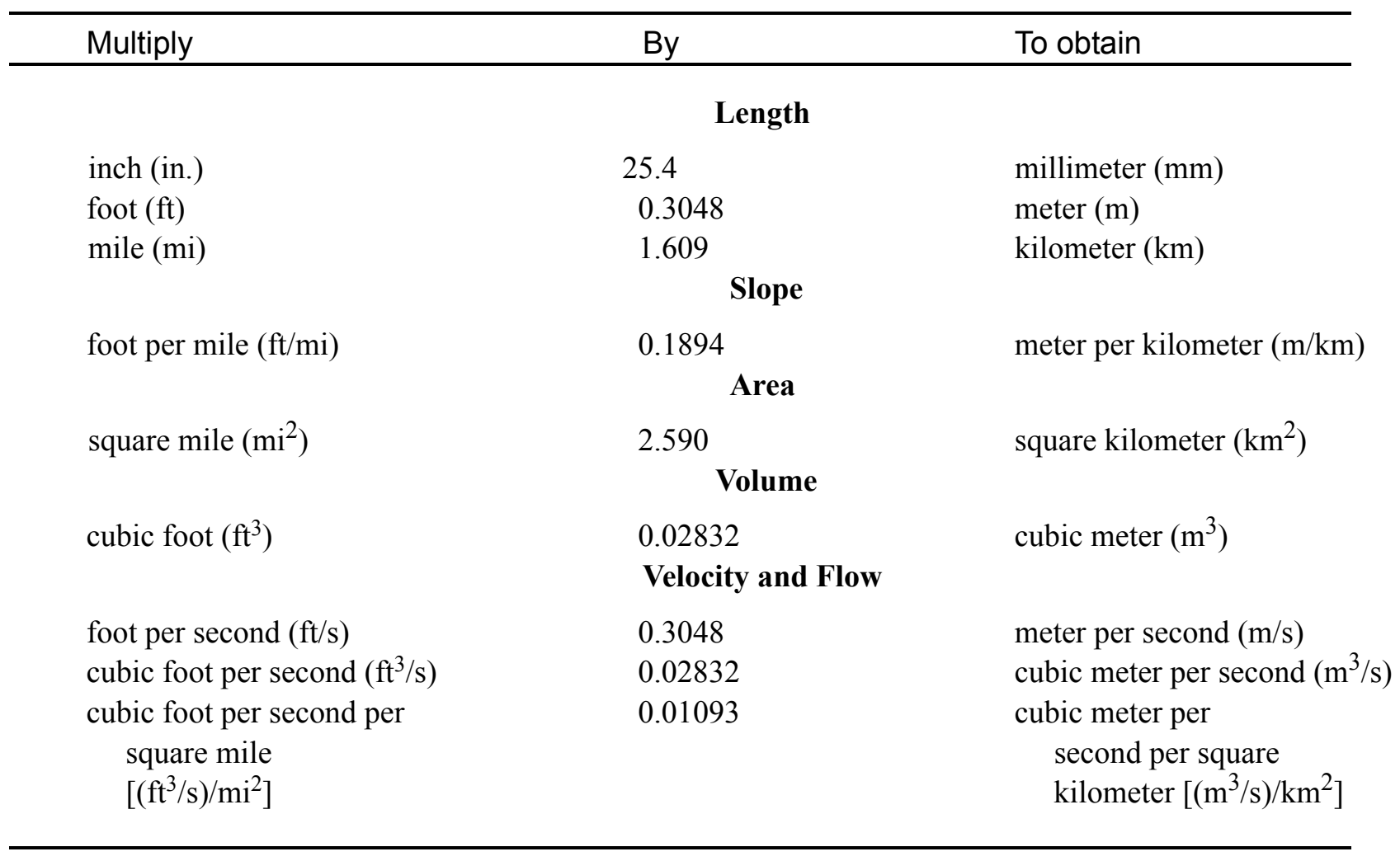

\section{OTHER ABBREVIATIONS}

$\begin{array}{lrlr}\mathrm{BF} & \text { bank full } & \text { LWW } & \text { left wingwall } \\ \mathrm{cfs} & \text { cubic feet per second } & \text { MC } & \text { main channel } \\ \mathrm{D}_{50} & \text { median diameter of bed material } & \text { RAB } & \text { right abutment } \\ \mathrm{DS} & \text { downstream } & \text { RABUT } & \text { face of right abutment } \\ \mathrm{elev} & \text { elevation } & \text { RB } & \text { right bank } \\ \mathrm{f} / \mathrm{p} & \text { flood plain } & \text { ROB } & \text { right overbank } \\ \mathrm{ft}^{2} & \text { square feet } & \text { RWW } & \text { right wingwall } \\ \mathrm{ft} / \mathrm{ft} & \text { feet per foot } & \text { TH } & \text { town highway } \\ \mathrm{JCT} & \text { junction } & \text { UB } & \text { under bridge } \\ \mathrm{LAB} & \text { left abutment } & \text { US } & \text { upstream } \\ \mathrm{LABUT} & \text { face of left abutment } & \text { USGS } & \text { United States Geological Survey } \\ \mathrm{LB} & \text { left bank } & \text { VTAOT Vermont Agency of Transportation } \\ \mathrm{LOB} & \text { left overbank } & \text { WSPRO } & \text { water-surface profile model }\end{array}$

In this report, the words "right" and "left" refer to directions that would be reported by an observer facing downstream. Sea level: In this report, "sea level" refers to the National Geodetic Vertical Datum of 1929-- a geodetic datum derived from a general adjustment of the first-order level nets of the United States and Canada, formerly called Sea Level Datum of 1929.

In the appendices, the above abbreviations may be combined. For example, USLB would represent upstream left bank. 


\title{
LEVEL II SCOUR ANALYSIS FOR BRIDGE 86 (VERNVT01420086) ON STATE ROUTE 142, CROSSING BROAD BROOK, VERNON, VERMONT
}

\author{
By Michael A. Ivanoff
}

\section{INTRODUCTION AND SUMMARY OF RESULTS}

This report provides the results of a detailed Level II analysis of scour potential at structure VERNVT01420086 on State Route 142 crossing Broad Brook, Vernon, Vermont (figures 1-8). A Level II study is a basic engineering analysis of the site, including a quantitative analysis of stream stability and scour (U.S. Department of Transportation, 1993). Results of a Level I scour investigation also are included in Appendix E of this report. A Level I investigation provides a qualitative geomorphic characterization of the study site. Information on the bridge, gleaned from Vermont Agency of Transportation (VTAOT) files, was compiled prior to conducting Level I and Level II analyses and is found in Appendix D.

The site is in the New England Upland section of the New England physiographic province in southeastern Vermont. The $23.7-\mathrm{mi}^{2}$ drainage area is in a predominantly rural and forested basin. In the vicinity of the study site, the surface cover is primarily forest with the exception of the downstream left bank which is a wetland.

In the study area, Broad Brook has an incised, meandering channel with a slope of approximately $0.001 \mathrm{ft} / \mathrm{ft}$, an average channel top width of $132 \mathrm{ft}$ and an average bank height of $3 \mathrm{ft}$. The channel bed material ranges from silt to cobbles with a median grain size $\left(\mathrm{D}_{50}\right)$ of $80.0 \mathrm{~mm}(0.262 \mathrm{ft})$. The geomorphic assessment at the time of the Level I and Level II site visit on August 14, 1996, indicated that the reach was vertically and laterally unstable.

The State Route 142 crossing of Broad Brook is a 98-ft-long, two-lane bridge consisting of two steel-beam spans with a maximum span length of 47 feet (Vermont Agency of Transportation, written communication, March 30, 1995). The bridge is supported by vertical, concrete abutments with spill-through slopes and a concrete pier. The channel is skewed approximately 30 degrees to the opening while there is no opening-skew-toroadway. 
A scour hole $2 \mathrm{ft}$ deeper than the mean thalweg depth was observed along the left bank side of the pier during the Level I assessment. There was also a scour hole $1 \mathrm{ft}$ deeper than the mean thalweg depth observed along the length of the right abutment. The only scour protection measure at the site was type- 2 stone fill (less than 36 inches diameter) along the entire base length of the spill-through slopes. Additional details describing conditions at the site are included in the Level II Summary and Appendices D and E.

Scour depths and recommended rock rip-rap sizes were computed using the general guidelines described in Hydraulic Engineering Circular 18 (Richardson and others, 1995). Total scour at a highway crossing is comprised of three components: 1) long-term streambed degradation; 2) contraction scour (due to accelerated flow caused by a reduction in flow area at a bridge) and; 3 ) local scour (caused by accelerated flow around piers and abutments). Total scour is the sum of the three components. Equations are available to compute depths for contraction and local scour and a summary of the results of these computations follows.

There was no computed contraction scour for any modelled flows. Scour at the left abutment ranged from 13.2 to $15.9 \mathrm{ft}$ and at the right abutment ranged from 12.0 to $16.3 \mathrm{ft}$. The worst-case abutment scour occurred at the 500-year discharge. Pier scour ranged from 12.0 to $16.3 \mathrm{ft}$. The worst-case pier scour occurred at the incipient-overtopping discharge. Additional information on scour depths and depths to armoring are included in the section titled "Scour Results". Scoured-streambed elevations, based on the calculated scour depths, are presented in tables 1 and 2. A cross-section of the scour computed at the bridge is presented in figure 8. Scour depths were calculated assuming an infinite depth of erosive material and a homogeneous particle-size distribution.

It is generally accepted that the Froehlich equation (abutment scour) gives "excessively conservative estimates of scour depths" (Richardson and others, 1995, p. 47). Usually, computed scour depths are evaluated in combination with other information including (but not limited to) historical performance during flood events, the geomorphic stability assessment, existing scour protection measures, and the results of the hydraulic analyses. Therefore, scour depths adopted by VTAOT may differ from the computed values documented herein. 


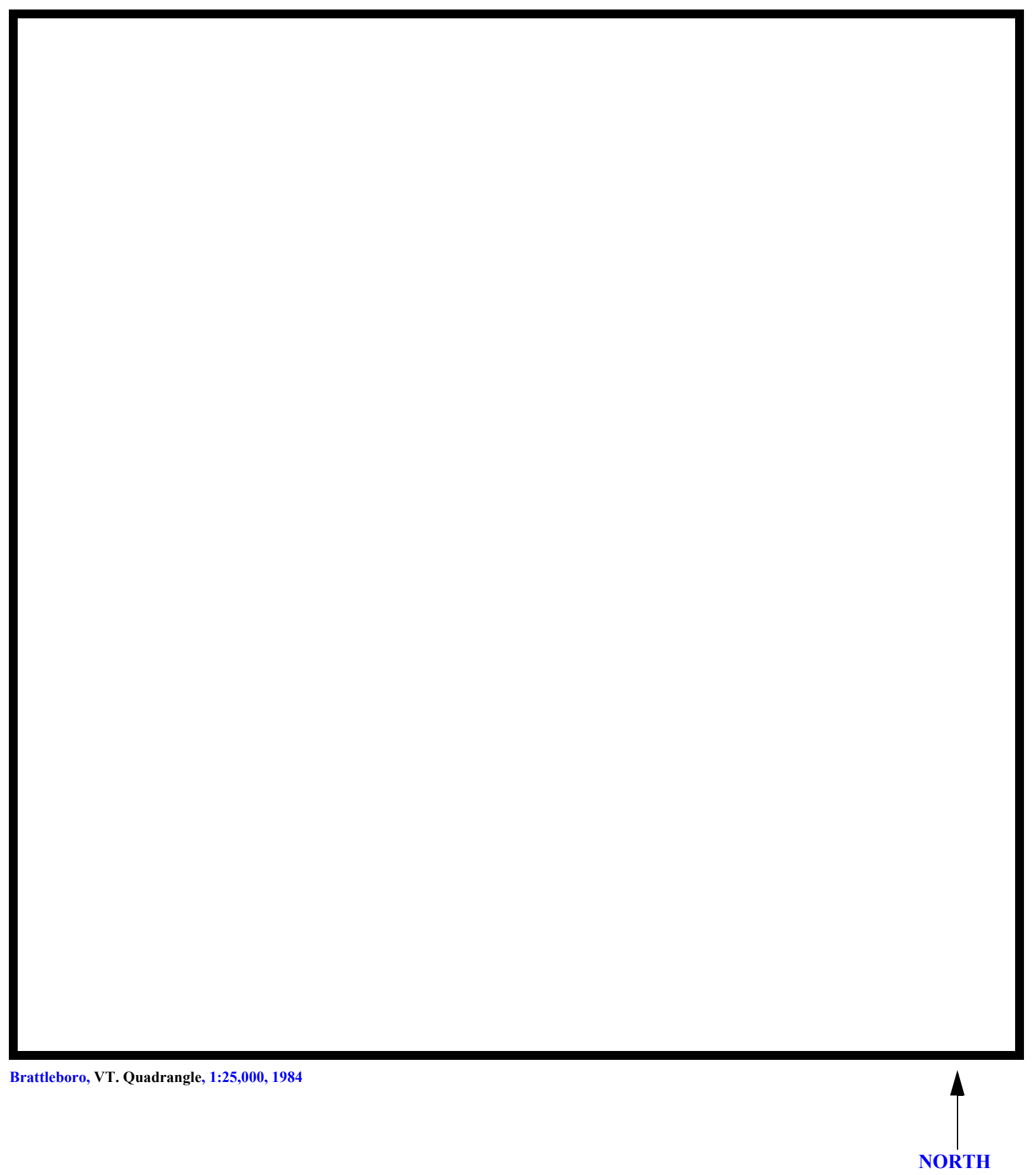

Figure 1. Location of study area on USGS 1:25,000 scale map. 
Figure 2. Location of study area on Vermont Agency of Transportation town highway map. 

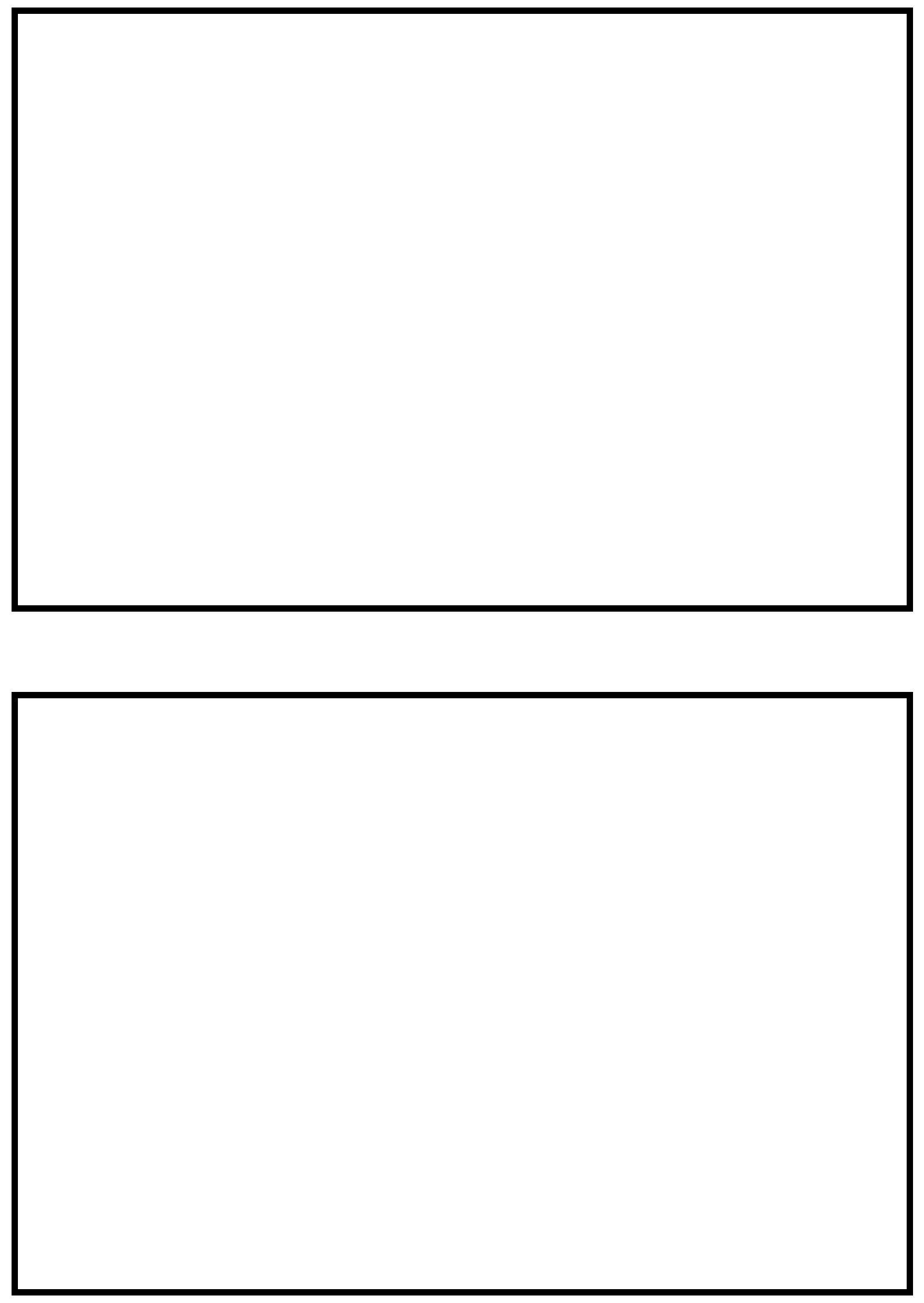

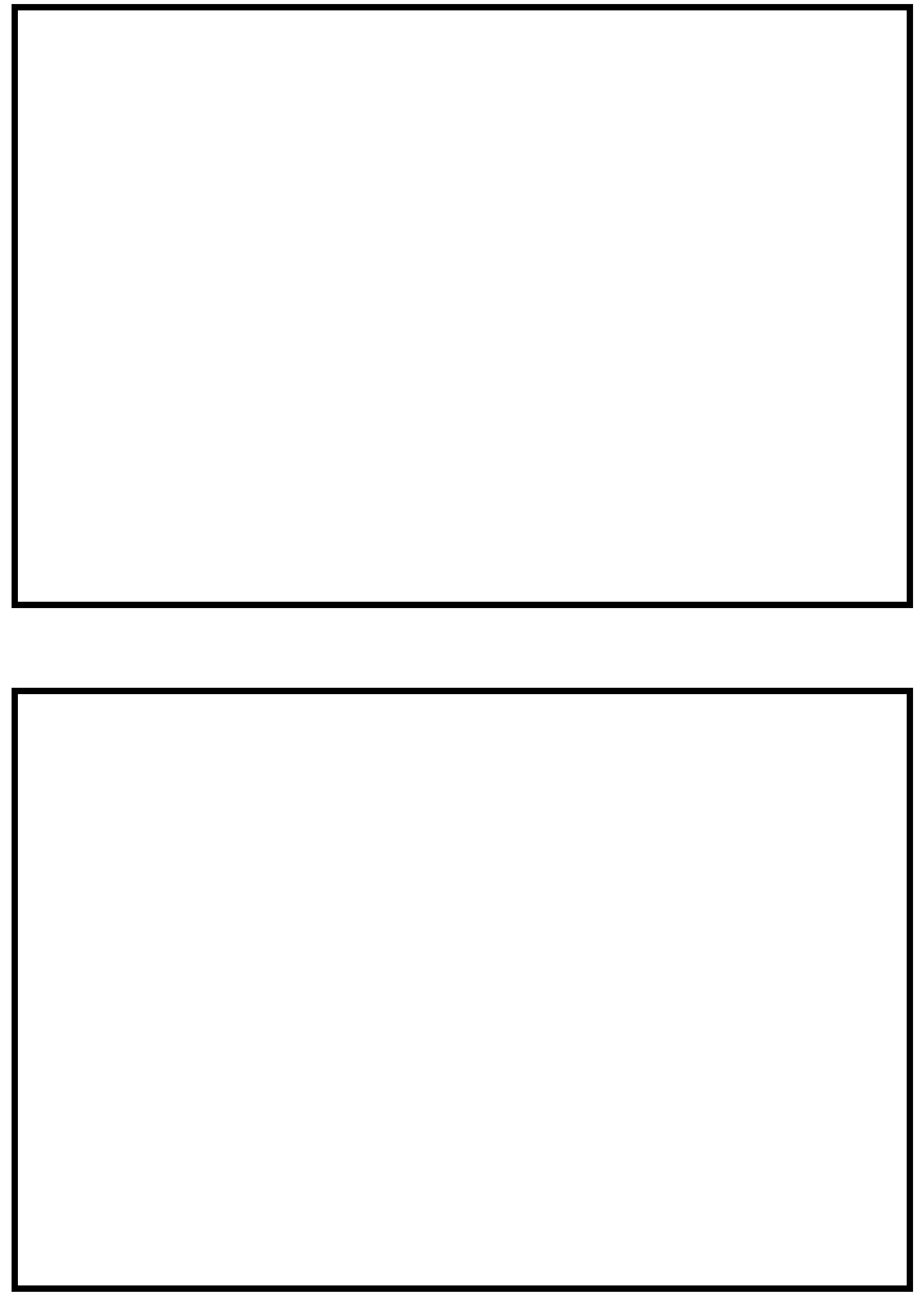


\section{LEVEL II SUMMARY}

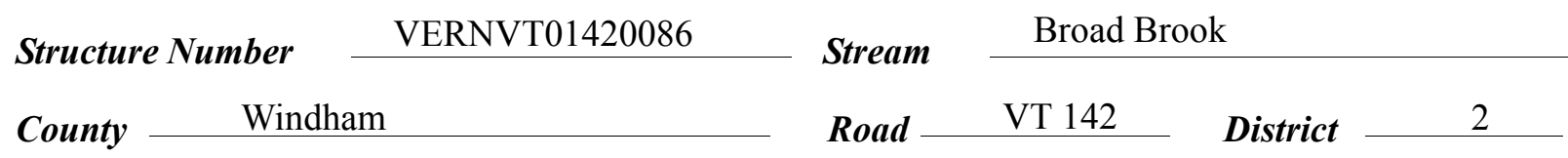

\section{Description of Bridge}

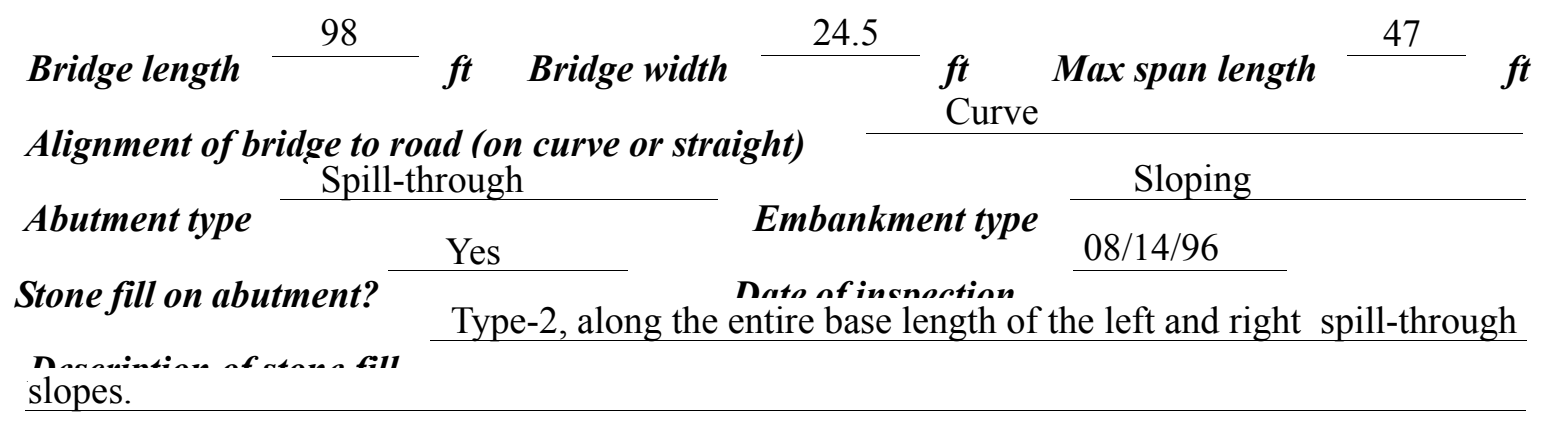

Vertical abutment walls and pier are concrete with stone spill-through slopes along the banks. There is a 2 feet deep scour hole along the left bank side of the pier and along the entire base length of the spill-through slopes.

Yes $\quad 30$

Is bridge skewed to flood flow according to Yes 'survey? Angle

There is a moderate channel bend in the US and DS reach. A scour hole has developed in the location where the bend impacts the US LB and DS RB extending through the bridge.

Debris accumulation on bridge at time of Level I or Level II site visit:

\begin{tabular}{|c|c|c|c|}
\hline & $\begin{array}{c}\text { Date of insnortion } \\
08 / 14 / 96 \\
\end{array}$ & $\begin{array}{l}\text { Percent of ofhmust } \\
\text { blocked inortzontatly }\end{array}$ & $\begin{array}{l}\text { Percent of } 0 \\
\text { blocked verticatty }\end{array}$ \\
\hline & $08 / 14 / 96$ & 0 & 0 \\
\hline
\end{tabular}

Level II

High. There are cut banks and trees leaning over the channel upstream.

Also debris at the pier and at the upstream end of the US RB point bar.

Potential for debris

The upstream right bank point bar directs flow along the left bank through the bridge resulting in Doscriho anv foaturos noar ar at tho hridoo that mav affort flow, (includo ahsorvation dato) a significant scour hole as of 08/14/96. 


\section{Description of the Geomorphic Setting}

General topography The channel is located in a moderate relief valley with wide flood plains and steep valley walls on both sides.

Geomorphic conditions at bridge site: downstream (DS), upstream (US)

Date of inspection $\quad 08 / 14 / 96$

DS left: $\quad$ Wide flood plain.

DS right: $\quad$ Moderately sloped bank to a wide flood plain.

US left: $\quad$ Moderately sloped bank to a wide flood plain.

US right: Wide flood plain.

\section{Description of the Channel}

\begin{tabular}{|c|c|c|c|}
\hline \multirow[b]{2}{*}{ Average top width } & & \multirow[b]{2}{*}{ Average depth } & \multirow{2}{*}{$\frac{3}{\text { Organics to Cobbles }}$} \\
\hline & & & \\
\hline \multicolumn{2}{|c|}{ Predominant bed material } & Bank material & Meandering with \\
\hline semi-alluvial channel & daries and a wide flood plain. & $\cdot$. & \\
\hline
\end{tabular}

$08 / 14 / 96$

Vegetative co ${ }^{1}$ Brush and wetland.

DS left: $\quad$ Trees and brush.

DS right: $\quad$ Trees and brush.

US left: $\quad$ Trees and brush.

US right: $\quad$ No

Do banks appear stable? The channel is meandering forming cut-banks and channel scour both dapstream and downstream.

The assessment of $08 /$

14/96 noted flow conditions are influenced by a vegetated point bar on the right bank side of the Describe any obstructions in channel and date of observation.

upstream channel. In addition, some debris is caught on the point bar and pier in the upstream

channel. 


\section{Hydrology}

Drainage area $\quad 23.7 \quad \boldsymbol{m i}^{2}$

Percentage of drainage area in physiographic provinces: (approximate)

Physiographic province/section New England/ New England Upland
Percent of drainage area 100
Is drainage area considered rural or urban?
Rural urbanization: None
Describe any significant

\section{Calculated Discharges $\quad 6,100$ \\ 4,170 $f t^{3} / s$ \\ $\quad \quad \mathrm{ft}^{3} / \mathrm{s}$}

The 100- and 500-year discharges are based on a

drainage area relationship [(19.8/23.7) exp 0.7] with bridge number 5 in Guilford. Bridge number 5 crosses Broad Brook upstream of this site and has flood frequency estimates available from the VTAOT database. The drainage area above bridge number 5 is 19.8 square miles. These values are within a range defined by several empirical flood frequency curves (Benson, 1962; Johnson and Tasker, 1974; FHWA, 1983; Potter, 1957a\&b; Talbot, 1887). 


\section{Description of the Water-Surface Profile Model (WSPRO) Analysis}

Datum for WSPRO analysis (USGS survey, sea level, VTAOT plans)

USGS survey

Datum tie between USGS survey and VTAOT plans $\quad$ Subtract 278.7 feet from the

USGS arbitrary survey datum to obtain the National Geodetic Vertical Datum of 1929.

Description of reference marks used to determine USGS datum.

$\mathrm{RM} 1$ is a chiseled $\mathrm{X}$

within a chiseled square on top of the US end of the left abutment (elev. $509.11 \mathrm{ft}$, arbitrary

survey datum). RM2 is a nail hole in the center of a chiseled $\mathrm{X}$ within a chiseled square on top

of the DS end of the right abutment (elev. $510.09 \mathrm{ft}$, arbitrary survey datum). RM3 is a U.S.

Coast and Geodetic Survey brass disk on the US end of

the left abutment of the DS railroad bridge (elev. $506.52 \mathrm{ft}$, arbitrary survey datum).

\begin{tabular}{|c|c|c|c|}
\hline${ }^{1}$ Cross-section & $\begin{array}{c}\text { Section } \\
\text { Reference } \\
\text { Distance (SRD) } \\
\text { in feet }\end{array}$ & $\begin{array}{l}{ }^{2} \text { Cross-section } \\
\text { development }\end{array}$ & Comments \\
\hline EXIT3 & -914 & 2 & $\begin{array}{l}\text { Downstream rail road bridge exit section at } \\
\text { mouth of brook (Templated from EXTEM) }\end{array}$ \\
\hline FULV1 & -857 & 1 & $\begin{array}{l}\text { Downstream rail road bridge full-valley section } \\
\text { (Templated from EXIT3) }\end{array}$ \\
\hline DSBRG & -857 & 1 & Downstream rail road bridge section \\
\hline RRWAY & -850 & 1 & Railroad grade section \\
\hline EXIT2 & -759 & 2 & $\begin{array}{l}\text { Modelled downstream rail road bridge approach } \\
\text { section (Templated from EXTEM) }\end{array}$ \\
\hline EXTEM & -571 & 1 & $\begin{array}{l}\text { Downstream railroad bridge approach section as } \\
\text { surveyed (Used as a template) }\end{array}$ \\
\hline EXITX & -81 & 1 & Bridge exit section \\
\hline FULLV & 0 & 2 & $\begin{array}{l}\text { Downstream full-valley section (Templated from } \\
\text { EXITX) }\end{array}$ \\
\hline BRIDG & 0 & 1 & Bridge section \\
\hline RDWAY & 13 & 1 & Road grade section \\
\hline APPRO & 119 & 2 & $\begin{array}{l}\text { Modelled approach section (Templated from } \\
\text { APTEM) }\end{array}$ \\
\hline ATEMP & 155 & 1 & $\begin{array}{l}\text { Approach section as surveyed (Used as a tem- } \\
\text { plate) }\end{array}$ \\
\hline
\end{tabular}

${ }^{1}$ For location of cross-sections see plan-view sketch included with Level I field form, Appendix E. 


\section{Data and Assumptions Used in WSPRO Model}

Hydraulic analyses of the reach were done by use of the Federal Highway Administration's WSPRO step-backwater computer program (Shearman and others, 1986, and Shearman, 1990). The analyses reported herein reflect conditions existing at the site at the time of the study. Furthermore, in the development of the model it was necessary to assume no accumulation of debris or ice at the site. Results of the hydraulic model are presented in the Bridge Hydraulic Summary, Appendix B, and figure 7.

Channel roughness factors (Manning's " $n$ ") used in the hydraulic model were estimated using field inspections at each cross section following the general guidelines described by Arcement and Schneider (1989). Final adjustments to the values were made during the modelling of the reach. Channel " $\mathrm{n}$ " values for the reach ranged from 0.030 to 0.060 , and overbank " $n$ " values ranged from 0.060 to 0.080 .

The water-surface elevation during the survey on August 14, 1996 was used as the starting water surface for the model at the section located at the mouth of Broad Brook (EXIT3). This elevation was the ambient backwater from Vernon dam on the Connecticut River. Although this water-surface elevation may not occur during a large flood event on Broad Brook, the extent of backwater from the Connecticut River while Broad Brook may be at peak flow is unknown. The method used follows the guidelines in HEC-18 (Richardson and others, 1995, p 26), which recommends using the lowest potential downstream water-surface elevation for scour analyses.

The surveyed approach section (ATEMP) was moved along the approach channel slope $(0.0006 \mathrm{ft} / \mathrm{ft})$ to establish the modelled approach section (APPRO), one bridge length upstream of the upstream face as recommended by Shearman and others (1986). This approach also provides a consistent method for determining scour variables. 


\section{Bridge Hydraulics Summary}

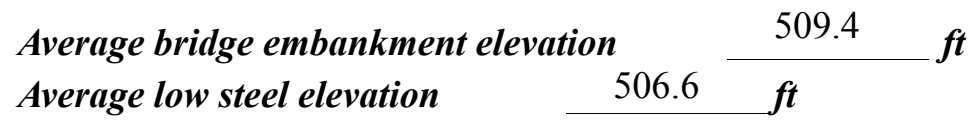

\begin{tabular}{|c|c|c|c|c|}
\hline \multirow{2}{*}{\multicolumn{3}{|c|}{$\begin{array}{l}\text { 100-year discharge } \\
\text { Water-surface elevation in bridge opening }\end{array}$}} & \multirow{2}{*}{\multicolumn{2}{|c|}{$502.2 \mathrm{ft}$}} \\
\hline & & & & \\
\hline \multirow{2}{*}{$\begin{array}{l}\text { Road overtopping? } \\
\text { Area of flow in brids }\end{array}$} & No & \multicolumn{2}{|c|}{ Discharge over road } & \multirow[t]{2}{*}{-} \\
\hline & ening & $482 \boldsymbol{f t}^{2}$ & $f^{2}$ & \\
\hline Average velocity in & opening & 8.6 & $f t / s$ & \\
\hline Maximum WSPRO & elocity a & t bridge & 11.0 & $\mathrm{t} / \mathrm{s}$ \\
\hline
\end{tabular}

Water-surface elevation at Approach section with bridge Water-surface elevation at Approach section without bridge

504.1 Amount of backwater caused by bridge

0.8 it

\section{3}

500-year discharge $\quad 6,100 \quad \mathrm{ft}^{3} / \mathrm{s}$

Water-surface elevation in bridge opening

Road overtopping? ___ Yes Discharge over road _ $125, \ldots 3 / s$

Area of flow in bridge opening

Average velocity in bridge opening 777 $\mathrm{ft}^{2}$

Maximum WSPRO tube velocity at bridge $7.1 \mathrm{ft} / \mathrm{s}$ 10.1 s

Water-surface elevation at Approach section with bridge

Water-surface elevation at Approach section without bridge

Amount of backwater caused by bridge

2.1

507.9

Incipient overtopping discharge $\quad 6,070 \mathrm{ft}^{3} / \mathrm{s}$

Water-surface elevation in bridge opening $504.6 \quad t$

Area of flow in bridge opening $673 \quad \mathrm{ft}^{2}$

Average velocity in bridge opening 9.0 $f t / s$

Maximum WSPRO tube velocity at bridge $11.6 \mathrm{ft} / \mathrm{s}$

Water-surface elevation at Approach section with bridge Water-surface elevation at Approach section without bridge 506.8 Amount of backwater caused by bridge $\quad 1.2$, t 


\section{Scour Analysis Summary}

\section{Special Conditions or Assumptions Made in Scour Analysis}

Scour depths were computed using the general guidelines described in Hydraulic Engineering Circular 18 (Richardson and others, 1995). Scour depths were calculated assuming an infinite depth of erosive material and a homogeneous particle-size distribution. The results of the scour analysis are presented in tables 1 and 2 and a graph of the scour depths is presented in figure 8.

Contraction scour for the 100-year and incipient road-overflow model was computed by use of the clearwater contraction scour equation (Richardson and others, 1995, p. 32, equation 20). The 500-year discharge resulted in unsubmerged orifice flow. Contraction scour at bridges with orifice flow is best estimated by use of the Chang pressure-flow scour equation (oral communication, J. Sterling Jones, October 4, 1996). Thus, contraction scour for the 500-year discharge was computed using the Chang equation (Richardson and others, 1995, p. 145-146). The results of Laursen's clear water contraction scour equation (Richardson and others, 1995, p. 32, equation 20) were also computed and can be found in Appendix F. The streambed armoring depths computed suggest that armoring will not limit the depth of contraction scour.

Abutment scour for the left abutment was computed by use of the Froehlich equation (Richardson and others, 1995, p. 48, equation 28). Variables for the Froehlich equation include the Froude number of the flow approaching the embankments, the length of the embankment blocking flow, and the depth of flow approaching the embankment less any roadway overtopping.

Scour at the right abutment for the 100- and 500-year discharges was computed by use of the HIRE equation (Richardson and others, 1995, p. 49, equation 29) because the HIRE equation is recommended when the length to depth ratio of the embankment blocking flow exceeds 25 . The variables used by the HIRE abutmentscour equation are defined the same as those used for the Froehlich abutment-scour equation.

Because the influence of scour processes on the spill-through embankment material is uncertain, the scour depth at the vertical concrete abutment walls is unknown. Therefore, the total scour depths were applied for the entire spill-through embankment below the elevation at the toe of each embankment and extended to the vertical concrete abutment wall.

Pier scour was computed by use of the Colorado State University pier scour equation (Richardson and others, 1995, p. 36, equation 21). Variables for the Colorado State University pier scour equation include the Froude number and depth of the flow approaching the pier, pier width, and correction factors for the pier nose shape, angle of attack of flow, bed condition, and armoring by bed material. Pier scour results for both the 100year and incipient roadway-overtopping discharges were less than the reults for the 500-year discharge. Thus, the pier scour for the 500-year event does not appear in figure 8 . 


\section{Scour Results}
100-yr discharge 500-yr discharge
Incipient overtopping (Scour depths in feet)

Contraction scour:

Main channel

Live-bed scour

Clear-water scour

Depth to armoring

Left overbank

Right overbank

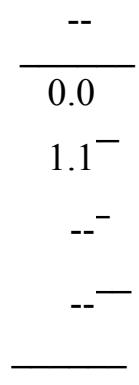

13.2

15.9

13.7

9.3

13.1

11.6

\section{Right abutment}

Pier scour

Pier 1

Pier 2

Pier 3

Abutments:

\section{Left abutment}

Right abutment

Piers:

Pier 1

Pier 2

\section{Riprap Sizing}
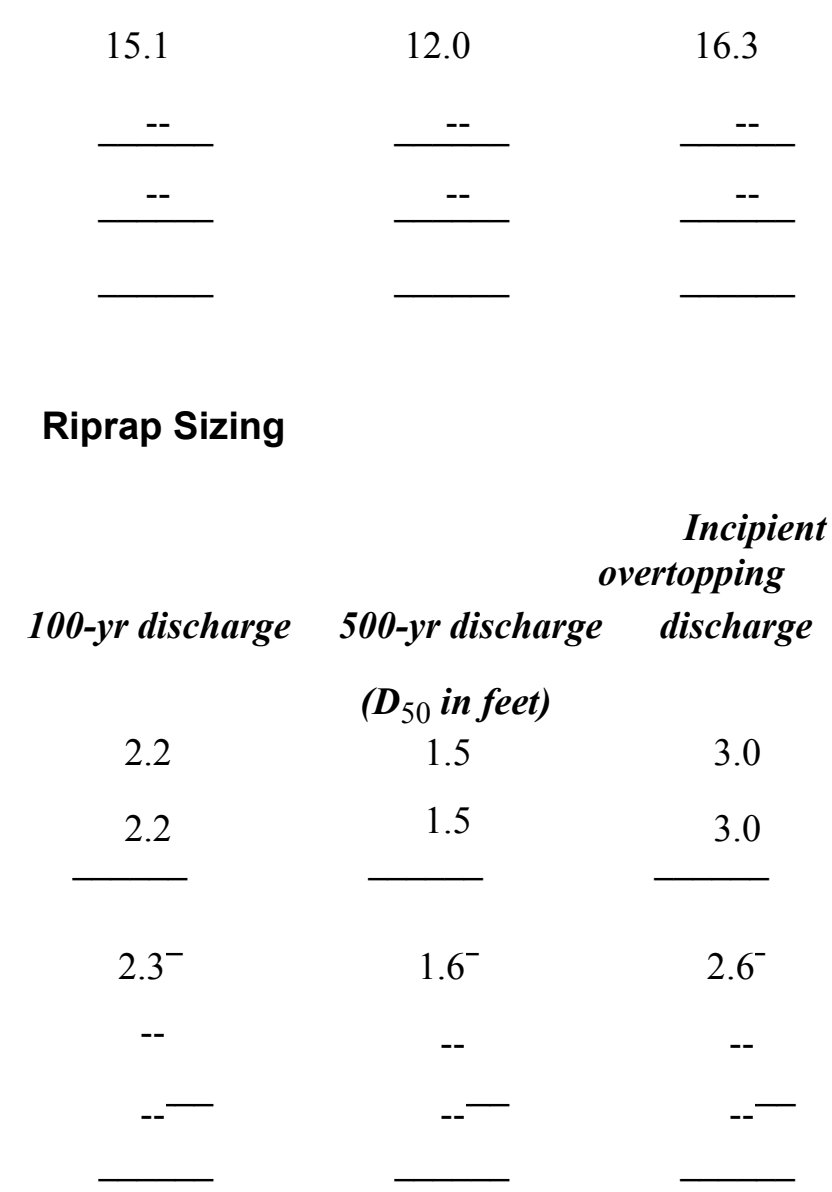


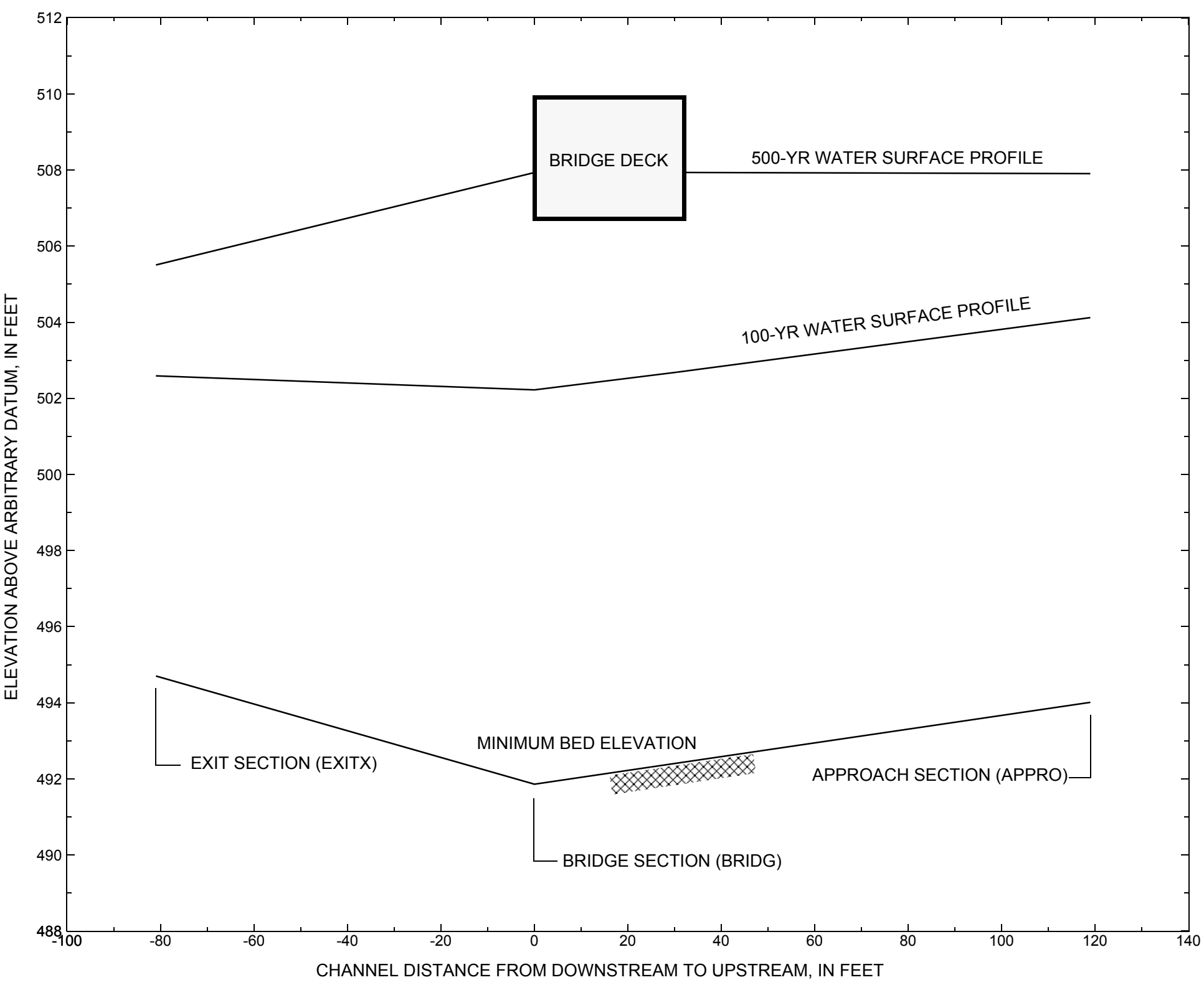

Figure 7. Water-surface profiles for the 100- and 500-yr discharges at structure VERNVT01420086 on State Route 142, crossing Broad Brook, Vernon, Vermont. 


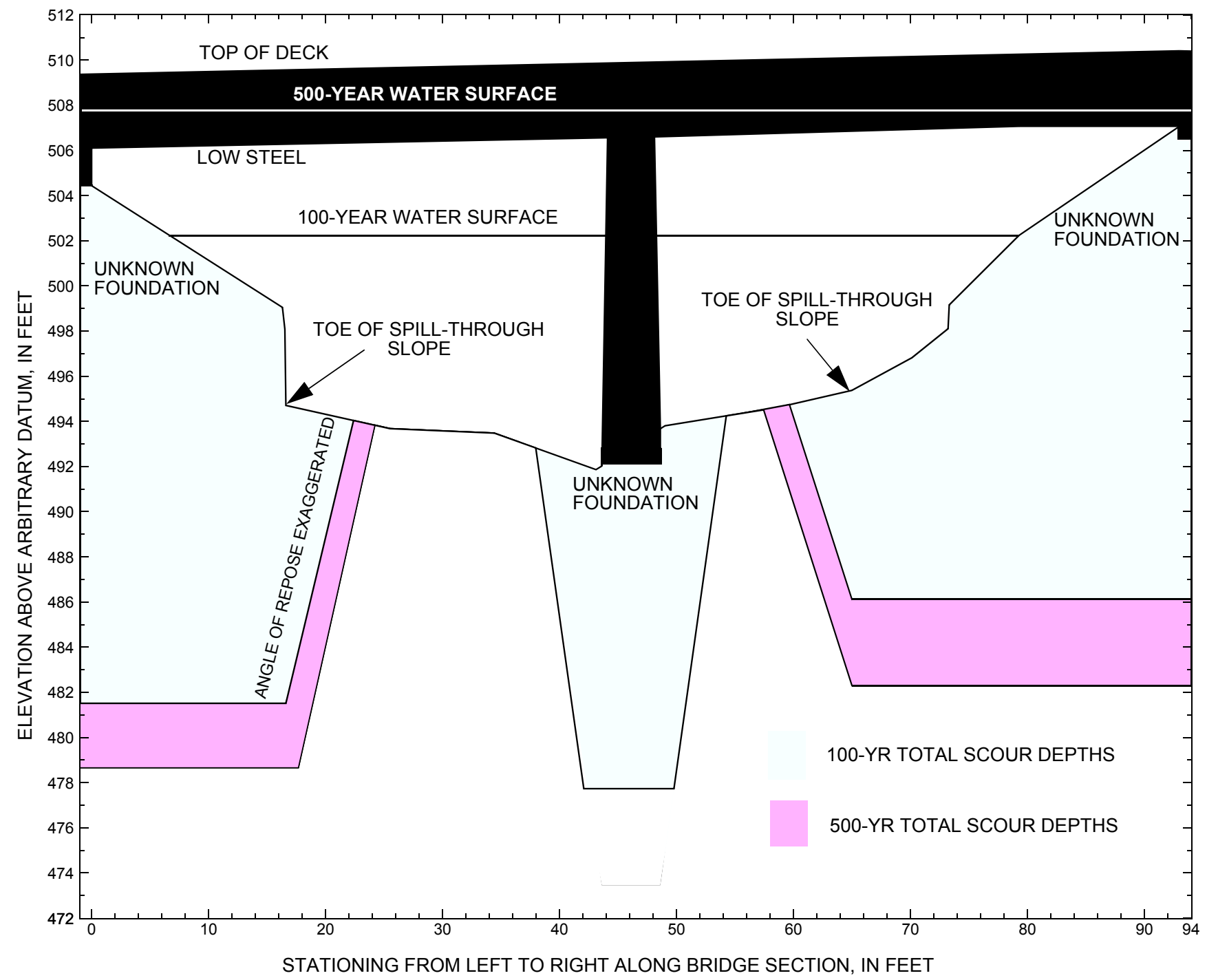

Figure 8. Scour elevations for the 100-yr and 500-yr discharges at structure VERNVT01420086 on State Route 142, crossing Broad Brook, Vernon, Vermont. 
Table 1. Remaining footing/pile depth at abutments for the 100-year discharge at structure VERNVT01420086 on State Route 142, crossing Broad Brook, Vernon, Vermont. [VTAOT, Vermont Agency of Transportation; --,no data]

\begin{tabular}{|c|c|c|c|c|c|c|c|c|c|c|c|}
\hline Description & Station $^{1}$ & $\begin{array}{l}\text { VTAOT } \\
\text { minimum } \\
\text { low-chord } \\
\text { elevation } \\
\text { (feet) }\end{array}$ & $\begin{array}{l}\text { Surveyed } \\
\text { minimum } \\
\text { low-chord } \\
\text { elevation }{ }^{2} \\
\text { (feet) }\end{array}$ & $\begin{array}{c}\text { Bottom of } \\
\text { footing } \\
\text { elevation } \\
\text { (feet) }\end{array}$ & $\begin{array}{c}\text { Channel } \\
\text { elevation at } \\
\text { abutment/ } \\
\text { pier }^{2} \\
\text { (feet) }\end{array}$ & $\begin{array}{l}\text { Contraction } \\
\text { scour depth } \\
\text { (feet) }\end{array}$ & $\begin{array}{l}\text { Abutment } \\
\text { scour } \\
\text { depth } \\
\text { (feet) }\end{array}$ & $\begin{array}{l}\text { Pier } \\
\text { scour } \\
\text { depth } \\
\text { (feet) }\end{array}$ & $\begin{array}{l}\text { Depth of } \\
\text { total scour } \\
\text { (feet) }\end{array}$ & $\begin{array}{c}\text { Elevation of } \\
\text { scour }^{2} \\
\text { (feet) }\end{array}$ & $\begin{array}{c}\text { Remaining } \\
\text { footing/pile } \\
\text { depth } \\
\text { (feet) }\end{array}$ \\
\hline \multicolumn{12}{|c|}{100 -yr. discharge is 4,170 cubic-feet per second } \\
\hline Left abutment & 0.0 & -- & 506.1 & -- & 504.4 & 0.0 & -- & -- & -- & -- & -- \\
\hline $\begin{array}{l}\text { Toe of spill- } \\
\text { through slope }\end{array}$ & 16.6 & -- & -- & -- & 494.7 & 0.0 & 13.2 & -- & 13.2 & 481.5 & -- \\
\hline Pier & 46.1 & -- & -- & -- & 492.8 & 0.0 & -- & 15.1 & 15.1 & 477.7 & -- \\
\hline $\begin{array}{l}\text { Toe of spill- } \\
\text { through slope }\end{array}$ & 65.0 & -- & -- & -- & 495.4 & 0.0 & 9.3 & -- & 9.3 & 486.1 & -- \\
\hline Right abutment & 93.0 & -- & 507.1 & -- & 507.1 & 0.0 & -- & -- & -- & -- & -- \\
\hline
\end{tabular}

1.Measured along the face of the most constricting side of the bridge.

2.Arbitrary datum for this study.

Table 2. Remaining footing/pile depth at abutments for the 500-year discharge at structure VERNVT01420086 on State Route 142, crossing Broad Brook, Vernon, Vermont. [VTAOT, Vermont Agency of Transportation; --, no data]

\begin{tabular}{|c|c|c|c|c|c|c|c|c|c|c|c|}
\hline Description & Station ${ }^{1}$ & $\begin{array}{l}\text { VTAOT } \\
\text { minimum } \\
\text { low-chord } \\
\text { elevation } \\
\text { (feet) }\end{array}$ & $\begin{array}{l}\text { Surveyed } \\
\text { minimum } \\
\text { low-chord } \\
\text { elevation }{ }^{2} \\
\text { (feet) }\end{array}$ & $\begin{array}{c}\text { Bottom of } \\
\text { footing } \\
\text { elevation } \\
\text { (feet) }\end{array}$ & $\begin{array}{c}\text { Channel } \\
\text { elevation at } \\
\text { abutment/ } \\
\text { pier }^{2} \\
\text { (feet) }\end{array}$ & $\begin{array}{l}\text { Contraction } \\
\text { scour depth } \\
\text { (feet) }\end{array}$ & $\begin{array}{l}\text { Abutment } \\
\text { scour } \\
\text { depth } \\
\text { (feet) }\end{array}$ & $\begin{array}{l}\text { Pier } \\
\text { scour } \\
\text { depth } \\
\text { (feet) }\end{array}$ & $\begin{array}{l}\text { Depth of } \\
\text { total scour } \\
\text { (feet) }\end{array}$ & $\begin{array}{c}\text { Elevation of } \\
\text { scour }^{2} \\
\text { (feet) }\end{array}$ & $\begin{array}{c}\text { Remaining } \\
\text { footing/pile } \\
\text { depth } \\
\text { (feet) }\end{array}$ \\
\hline \multicolumn{12}{|c|}{500 -yr. discharge is 6,100 cubic-feet per second } \\
\hline Left abutment & 0.0 & -- & 506.1 & -- & 504.4 & 0.0 & -- & -- & -- & -- & -- \\
\hline $\begin{array}{l}\text { Toe of spill- } \\
\text { through slope }\end{array}$ & 16.6 & -- & -- & -- & 494.7 & 0.0 & 15.9 & -- & 15.9 & 478.8 & -- \\
\hline Pier & 46.1 & -- & -- & -- & 492.8 & 0.0 & -- & 12.0 & 12.0 & 480.8 & -- \\
\hline $\begin{array}{l}\text { Toe of spill- } \\
\text { through slope }\end{array}$ & 65.0 & -- & -- & -- & 495.4 & 0.0 & 13.1 & -- & 13.1 & 482.3 & -- \\
\hline Right abutment & 93.0 & -- & 507.1 & -- & 507.1 & 0.0 & -- & -- & -- & -- & -- \\
\hline
\end{tabular}

1.Measured along the face of the most constricting side of the bridge.

2.Arbitrary datum for this study. 


\section{SELECTED REFERENCES}

Arcement, G.J., Jr., and Schneider, V.R., 1989, Guide for selecting Manning's roughness coefficients for natural channels and flood plains:

U.S. Geological Survey Water-Supply Paper 2339, 38 p.

Barnes, H.H., Jr., 1967, Roughness characteristics of natural channels: U.S. Geological Survey Water-Supply Paper 1849,213 p.

Benson, M. A., 1962, Factors Influencing the Occurrence of Floods in a Humid Region of Diverse Terrain: U.S. Geological Survey WaterSupply Paper 1580-B, 64 p.

Brown, S.A. and Clyde, E.S., 1989, Design of riprap revetment: Federal Highway Administration Hydraulic Engineering Circular No. 11, Publication FHWA-IP-89-016, 156 p.

Federal Highway Administration, 1993, Stream Stability and Scour at Highway Bridges: Participant Workbook: Federal Highway Administration Report FHWA-HI-91-011.

Froehlich, D.C., 1989, Local scour at bridge abutments in Ports, M.A., ed., Hydraulic Engineering--Proceedings of the 1989 National Conference on Hydraulic Engineering: New York, American Society of Civil Engineers, p. 13-18.

Hayes, D.C.,1993, Site selection and collection of bridge-scour data in Delaware, Maryland, and Virginia: U.S. Geological Survey WaterResources Investigation Report 93-4017, 23 p.

Interagency Advisory Committee on Water Data, 1982, Guidelines for determining flood flow frequency: U.S. Geological Survey, Bulletin 17B of the Hydrology Subcommittee, $190 \mathrm{p}$.

Johnson, C.G. and Tasker, G.D.,1974, Progress report on flood magnitude and frequency of Vermont streams: U.S. Geological Survey OpenFile Report 74-130, 37 p.

Lagasse, P.F., Schall, J.D., Johnson, F., Richardson, E.V., Chang, F., 1995, Stream Stability at Highway Structures: Federal Highway Administration Hydraulic Engineering Circular No. 20, Publication FHWA-IP-90-014, 144 p.

Laursen, E.M., 1960, Scour at bridge crossings: Journal of the Hydraulics Division, American Society of Civil Engineers, v. 86, no. HY2, p. 39-53.

Potter, W. D., 1957a, Peak rates of runoff in the Adirondack, White Mountains, and Maine woods area, Bureau of Public Roads

Potter, W. D., 1957b, Peak rates of runoff in the New England Hill and Lowland area, Bureau of Public Roads

Richardson, E.V. and Davis, S.R., 1995, Evaluating scour at bridges: Federal Highway Administration Hydraulic Engineering Circular No. 18, Publication FHWA-IP-90-017, 204 p.

Richardson, E.V., Simons, D.B., and Julien, P.Y., 1990, Highways in the river environment: Federal Highway Administration Publication FHWA-HI-90-016.

Ritter, D.F., 1984, Process Geomorphology: W.C. Brown Co., Debuque, Iowa, 603 p.

Shearman, J.O., 1990, User's manual for WSPRO--a computer model for water surface profile computations: Federal Highway Administration Publication FHWA-IP-89-027, 187 p.

Shearman, J.O., Kirby, W.H., Schneider, V.R., and Flippo, H.N., 1986, Bridge waterways analysis model; research report: Federal Highway Administration Publication FHWA-RD-86-108, 112 p.

Talbot, A.N., 1887, The determination of water-way for bridges and culverts.

U.S. Department of Transportation, 1993, Stream stability and scour at highway bridges, Participant Workbook: Federal Highway Administration Publication FHWA HI-91-011.

U.S. Geological Survey, 1984, Brattleboro, Vermont 7.5 X 15 Minute Series quadrangle map: U.S. Geological Survey Topographic Maps, Scale 1:25,000. 


\section{APPENDIX A: \\ WSPRO INPUT FILE}




\section{WSPRO INPUT FILE}

GR

GR

GR

GR

GR

GR

$\mathrm{N}$

SA

*

XS

*

*

BR

GR

GR

GR

GR

*

CD

$\mathrm{N}$

*

$\mathrm{XR}$

GR

GR

$\mathrm{XT}$

GR

GR

GR

GR

GR

GR

*

AS

GT

$\mathrm{N}$

SA

*

XS

GR

GR

GR

GR

GR

GR

$\mathrm{N}$
U.S. Geological Survey WSPRO Input File verno86a.wsp Hydraulic analysis for structure VERNVT01420086 Date: 16-JAN-97 Bridge \# 86 on VT 142 over Broad Brook in Vernon, VT BY MAI

$\begin{array}{lllllllllllllllllllll}6 & 29 & 30 & 552 & 553 & 551 & 5 & 16 & 17 & 13 & 3 & * & 15 & 14 & 23 & 21 & 11 & 12 & 4 & 7 & 3\end{array}$

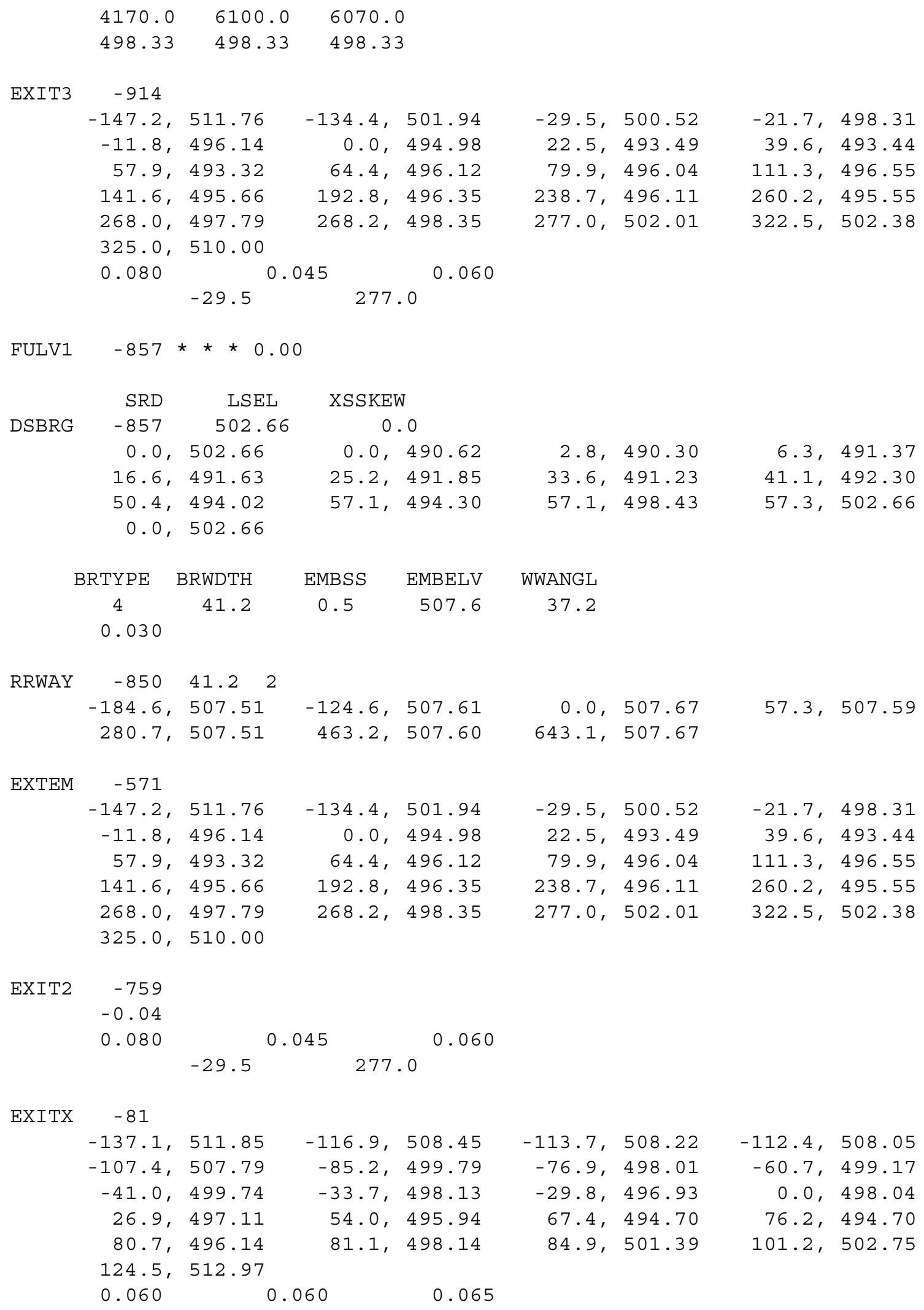

0.065

$6.3,491.37$ $41.1,492.30$ $57.3,502.66$ $33.6,491.23$ $57.1,498.43$ $57.3,507.59$ 
WSPRO INPUT FILE (continued)

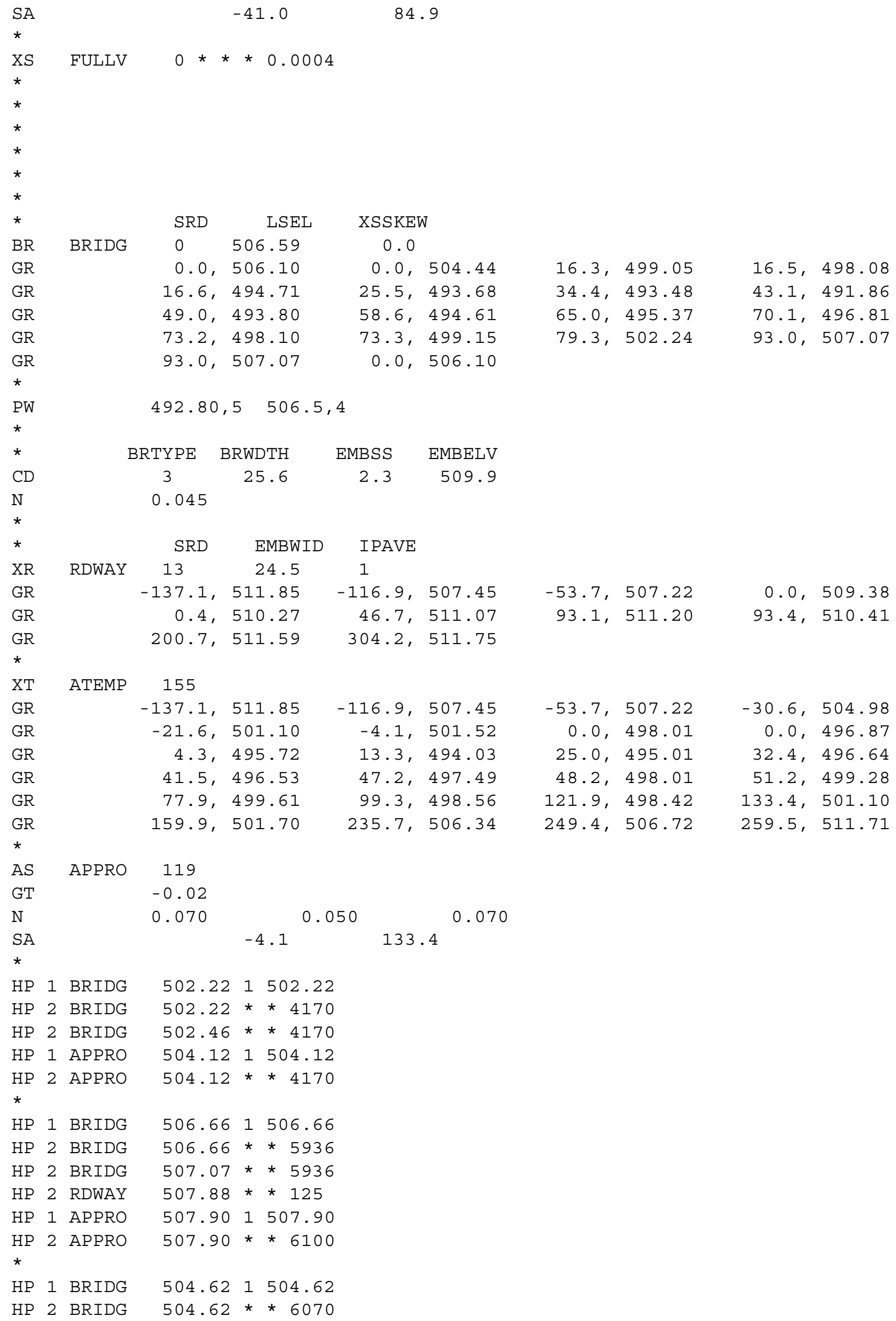




\section{APPENDIX B: \\ WSPRO OUTPUT FILE}




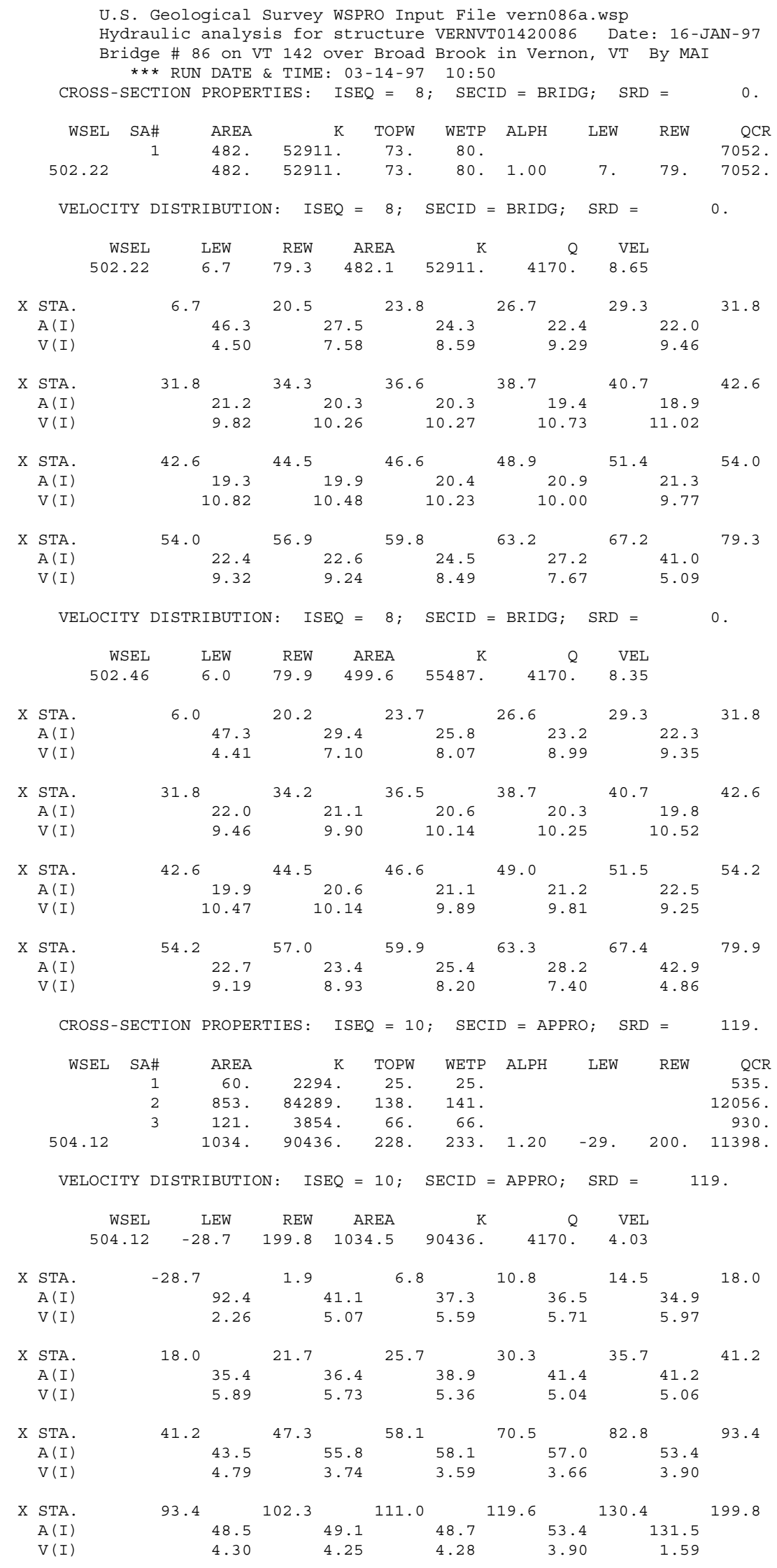




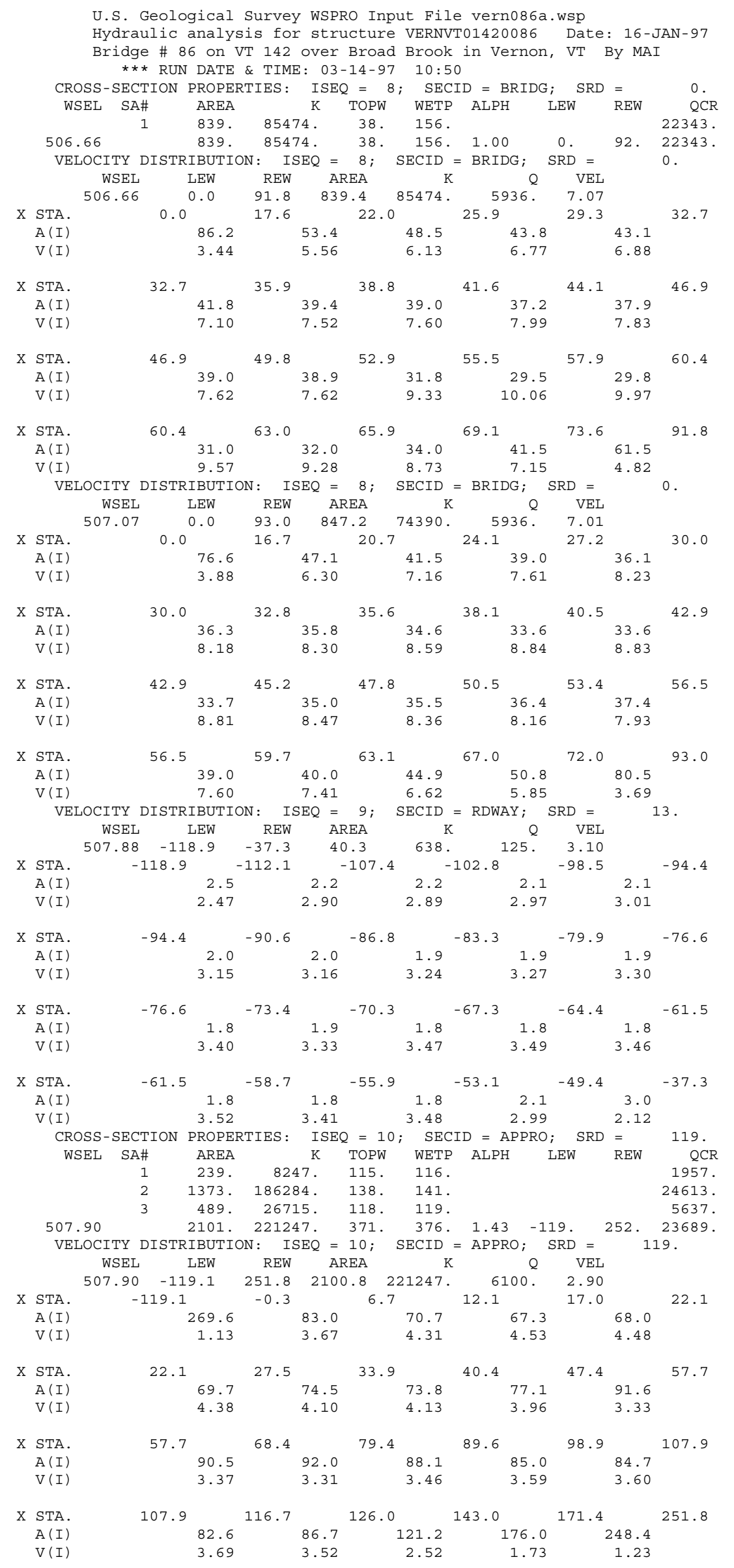




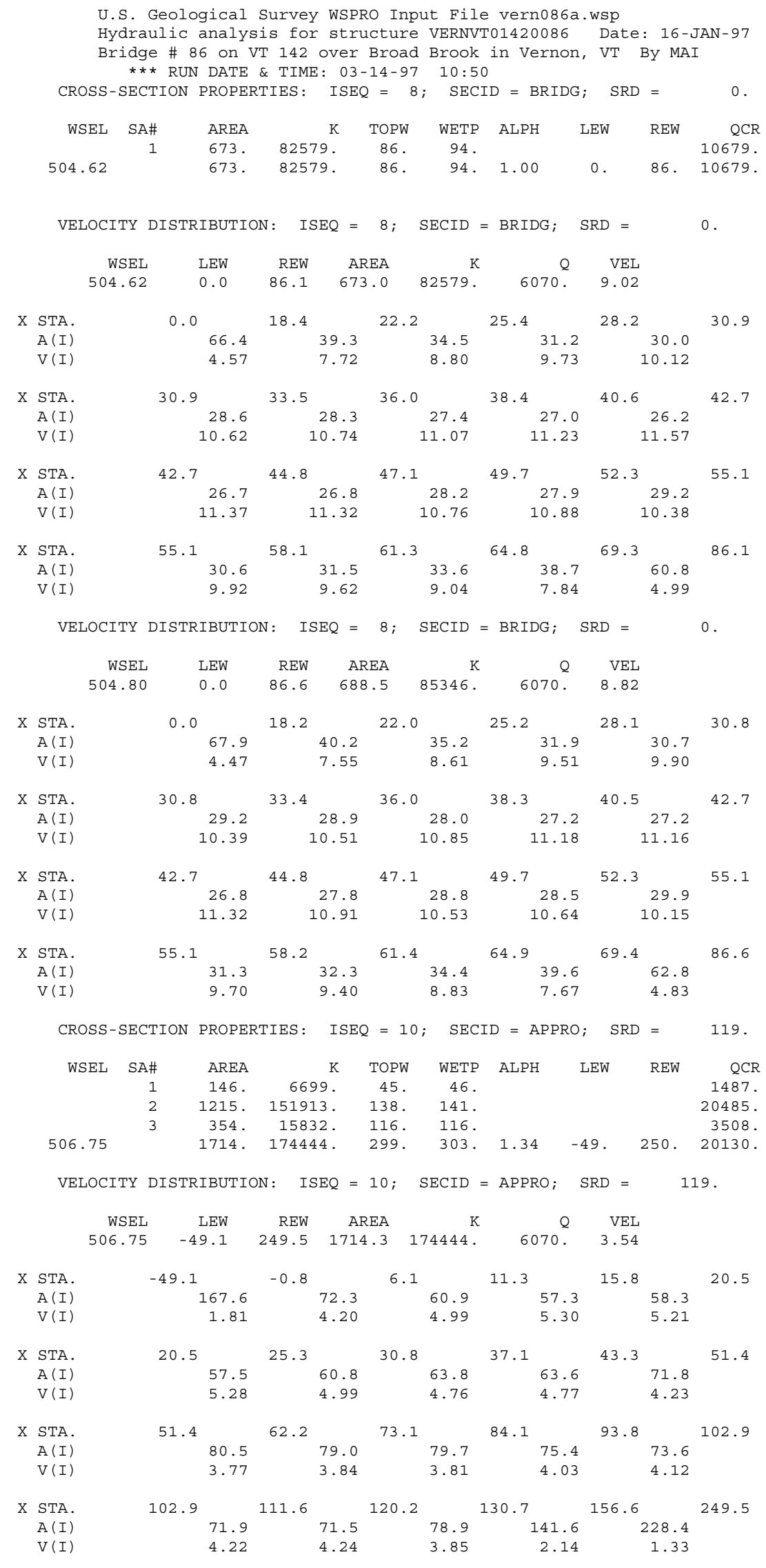


WSPRO OUTPUT FILE (continued)

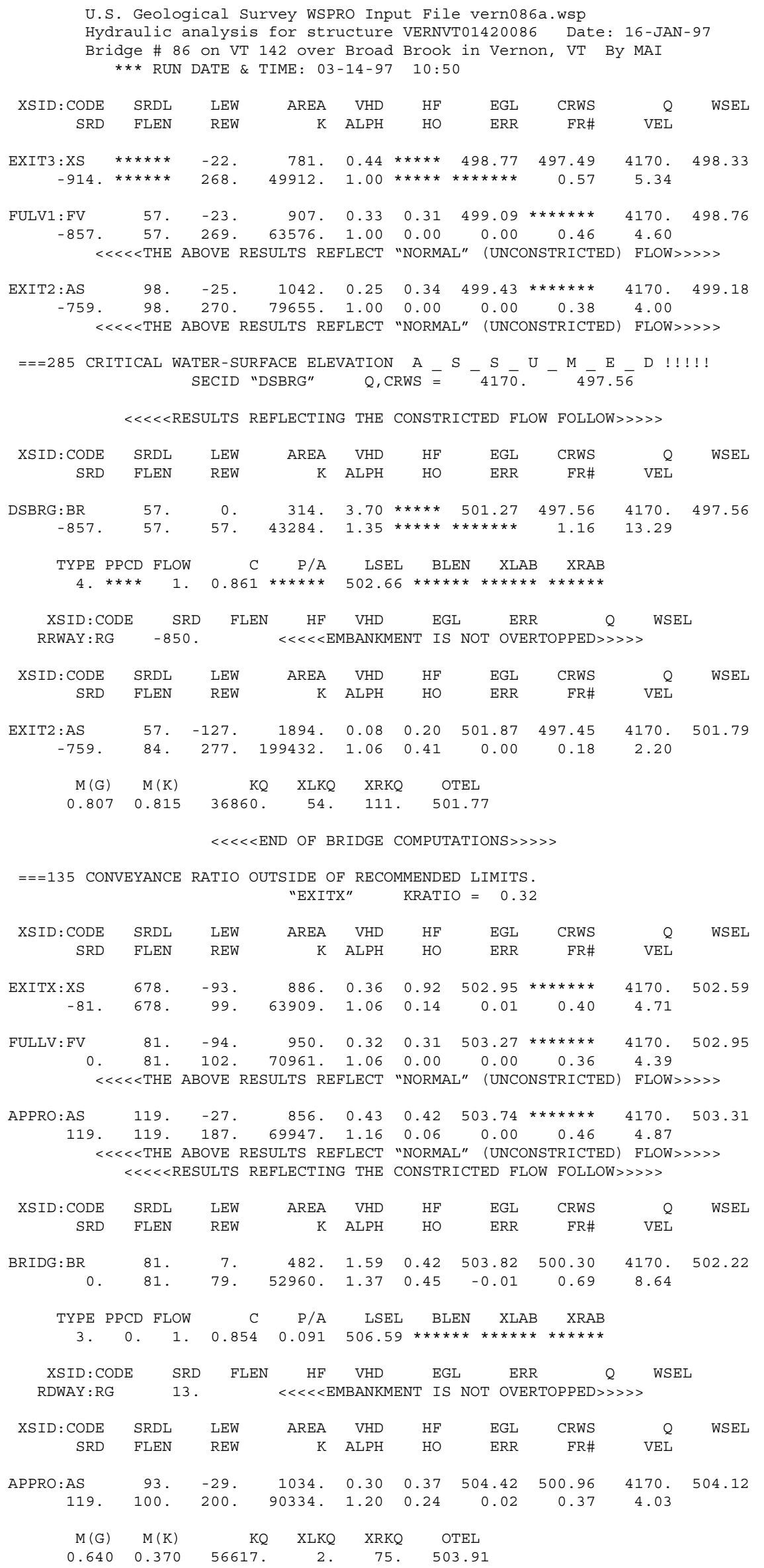


WSPRO OUTPUT FILE (continued)

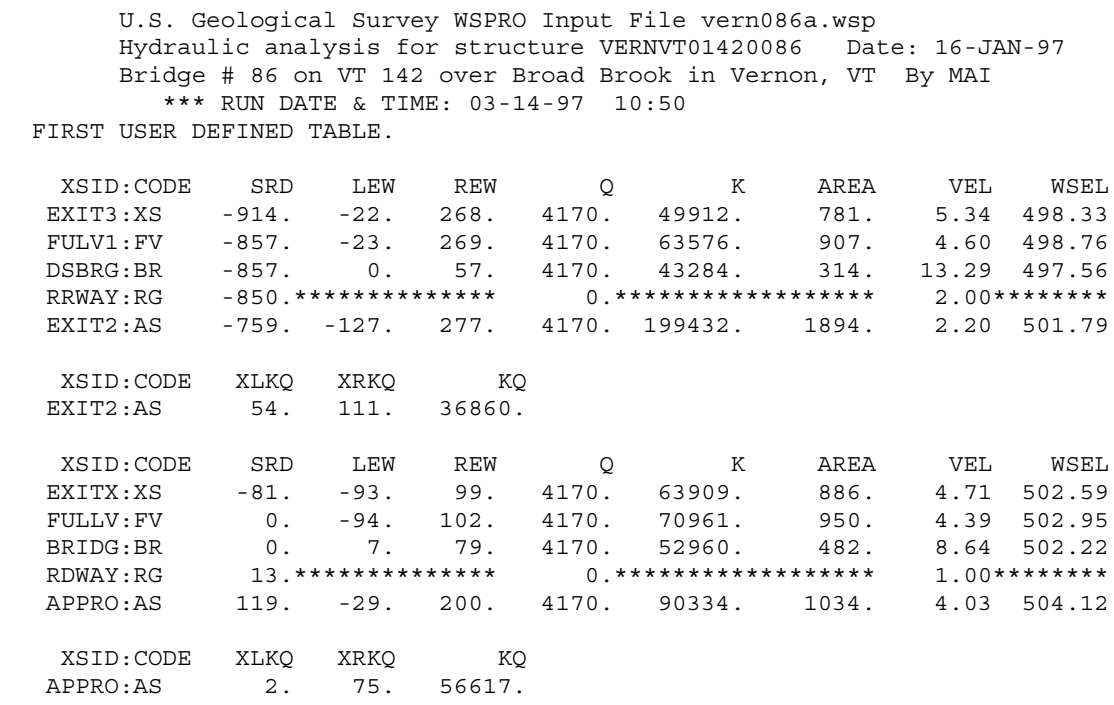

SECOND USER DEFINED TABLE.

\begin{tabular}{|c|c|c|c|c|c|c|c|c|c|}
\hline XSID : CODE & CRWS & FR\# & YMIN & YMAX & $\mathrm{HF}$ & $\mathrm{HO}$ & VHD & EGL & WSEL \\
\hline EXIT3:XS & 497.49 & 0.57 & 493.32 & $511.76 *$ & 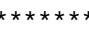 & 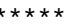 & 0.44 & 498.77 & 498.33 \\
\hline FULV1 : FV & 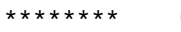 & 0.46 & 493.32 & 511.76 & 0.31 & 0.00 & 0.33 & 499.09 & 498.76 \\
\hline DSBRG : BR & 497.56 & 1.16 & 490.30 & $502.66 *$ & 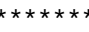 & 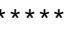 & 3.70 & 501.27 & 497.56 \\
\hline RRWAY : RG & 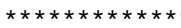 & $\star \star \star \star *$ & 507.51 & $507.67 *$ & $\star \star \star \star \star * \star * *$ & $F *$ & $\star * \star * \star * \star$ & $\pi * \star \star \star \star \star \star *$ & 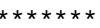 \\
\hline EXIT2:AS & 497.45 & 0.18 & 493.28 & 511.72 & 0.20 & 0.41 & 0.08 & 501.87 & 501.79 \\
\hline EXITX:XS & $\star * * * * * * *$ & 0.40 & 494.70 & 512.97 & 0.92 & 0.14 & 0.36 & 502.95 & 502.59 \\
\hline FULLV : FV & 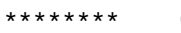 & 0.36 & 494.73 & 513.00 & 0.31 & 0.00 & 0.32 & 503.27 & 502.95 \\
\hline BRIDG : BR & 500.30 & 0.69 & 491.86 & 507.07 & 0.42 & 0.45 & 1.59 & 503.82 & 502.22 \\
\hline RDWAY : RG & 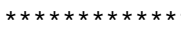 & 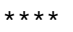 & 507.22 & $511.85 * *$ & $* * \star * \star * *$ & 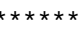 & $* \star \star \star * * *$ & 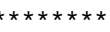 & 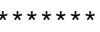 \\
\hline APPRO : AS & 500.96 & 0.37 & 494.01 & 511.83 & 0.37 & 0.24 & 0.30 & 504.42 & 504.1 \\
\hline
\end{tabular}

U.S. Geological Survey WSPRO Input File verno86a.wsp

Hydraulic analysis for structure VERNVT01420086 Date: 16-JAN-97

Bridge \# 86 on VT 142 over Broad Brook in Vernon, VT BY MAI

*** RUN DATE \& TIME: 03-14-97 10:50

$\begin{array}{rrrrrrrrrr}\text { XSID }: \text { CODE } & \text { SRDL } & \text { LEW } & \text { AREA } & \text { VHD } & \text { HF } & \text { EGL } & \text { CRWS } & \text { Q } & \text { WSEL } \\ \text { SRD } & \text { FLEN } & \text { REW } & \text { K } & \text { ALPH } & \text { HO } & \text { ERR } & \text { FR\# } & \text { VEL } & \\ & & & & & & & & & \\ \text { EXIT3 }: \text { XS } & * * * * * * & -22 . & 781 . & 0.95 * * * * * & 499.28 & 498.04 & 6100 . & 498.33 \\ -914 . * * * * * * & 268 . & 49912 . & 1.00 * * * * * & * * * * * * * & 0.84 & 7.81 & \end{array}$

$===135$ CONVEYANCE RATIO OUTSIDE OF RECOMMENDED LIMITS .

"FULV1" KRATIO $=1.63$

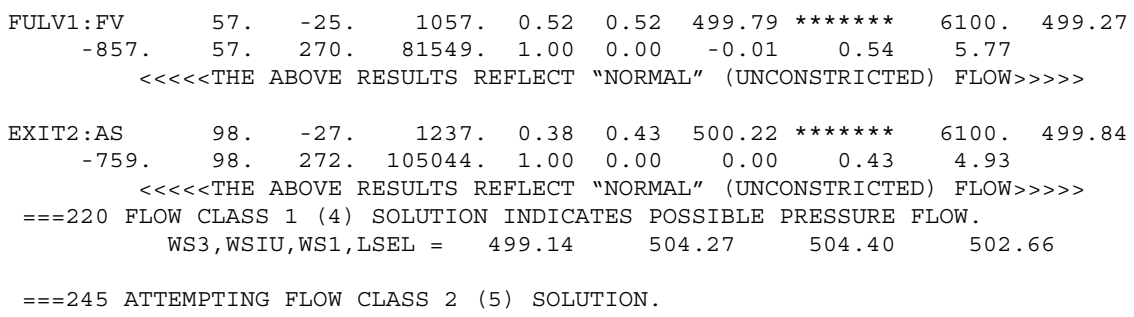




\section{WSPRO OUTPUT FILE (continued)}

$<<<<$ END OF BRIDGE COMPUTATIONS $>>>>>$

$===135$ CONVEYANCE RATIO OUTSIDE OF RECOMMENDED LTMTTS "EXITX" KRATIO $=0.31$

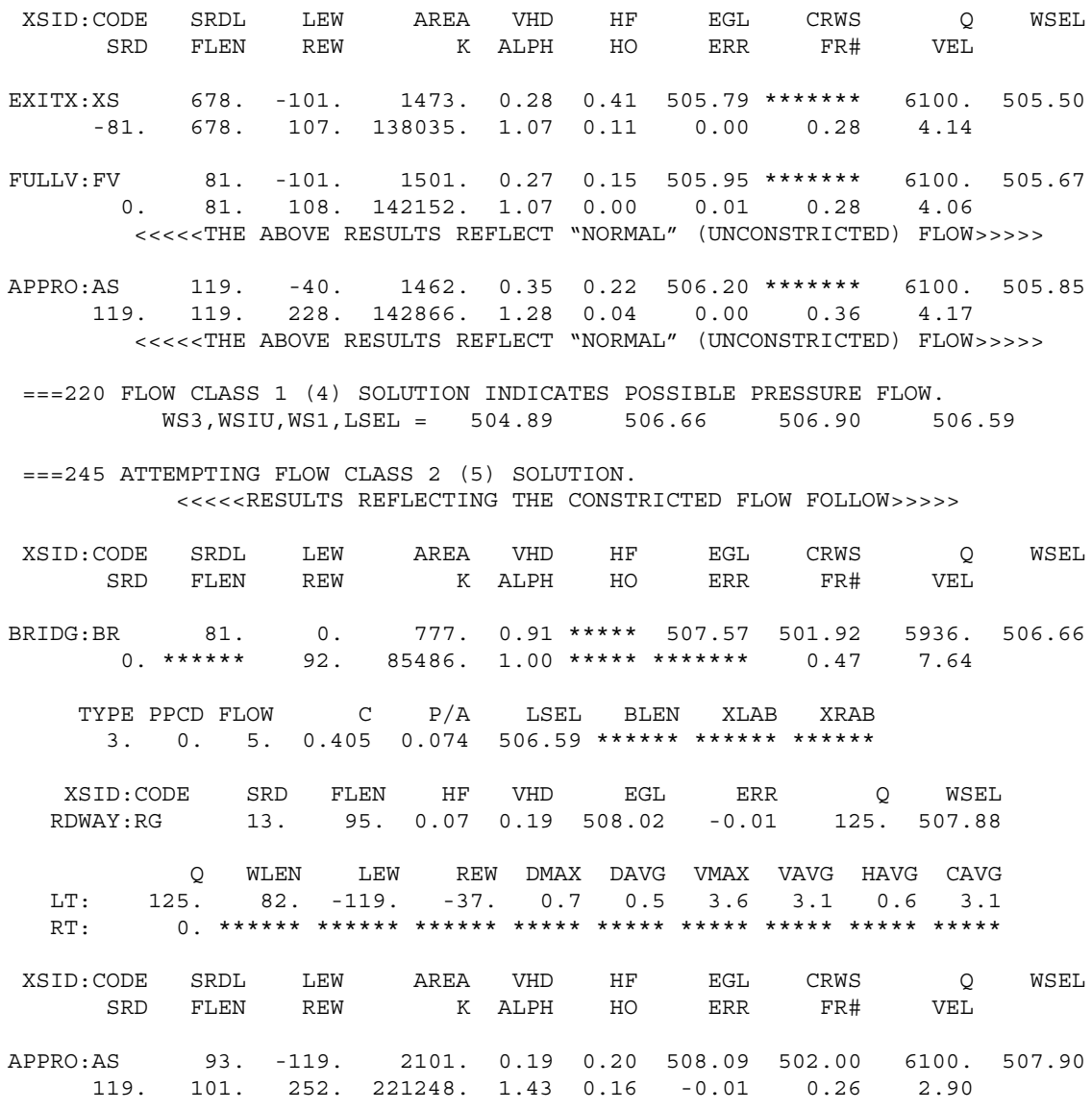

FIRST USER DEFINED TABLE.

\begin{tabular}{|c|c|c|c|c|c|c|c|c|}
\hline XSID : CODE & SRD & LEW & REW & $\mathrm{Q}$ & $\mathrm{K}$ & AREA & VEL & WSEL \\
\hline EXIT3:XS & -914. & -22 & 268 . & 6100. & 49912. & 781. & 7.81 & 498.33 \\
\hline FULV1 : FV & -857. & -25 & 270 . & 6100. & 81549 . & 1057. & 5.77 & 499.27 \\
\hline DSBRG : BR & -857. & 0 & 57. & 6195. & 81633 & 605 & 10.23 & 502.66 \\
\hline RRWAY : RG & \multicolumn{3}{|c|}{$-850 . * * * * \star * * \star * * * \star * * *$} & \multicolumn{3}{|c|}{ 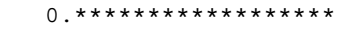 } & \multicolumn{2}{|c|}{$2.00 * * \star * * * * *$} \\
\hline EXIT2 : AS & -759. & -139. & 323. & 6100. & 448228 . & 3446 . & 1.77 & 505.21 \\
\hline XSID : CODE & XLKQ & XRKQ & & & & & & \\
\hline \multicolumn{9}{|c|}{ 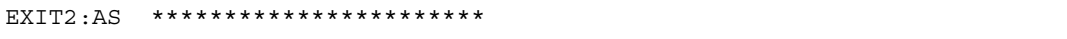 } \\
\hline XSID : CODE & SRD & LEW & REW & Q & $\mathrm{K}$ & AREA & VEL & WSEL \\
\hline EXITX:XS & -81 & -101. & 107. & 6100. & 138035. & 1473. & 4.14 & 505.50 \\
\hline FULLV : FV & 0 . & -101. & 108. & 6100. & 142152 . & 1501. & 4.06 & 505.67 \\
\hline BRIDG : BR & 0 . & 0 & 92. & 5936. & 85486 & 777 & 7.64 & 506.66 \\
\hline RDWAY : RG & 13. * & $\star * \star * *$ & 125. & 125. & 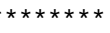 & 0 & 1.00 & 507.88 \\
\hline APPRO: AS & 119. & -119. & 252 . & 6100. & 221248 . & 2101. & 2.90 & 507.90 \\
\hline
\end{tabular}

SECOND USER DEFINED TABLE.

$\begin{array}{lrrrrrrrrr}\text { XSID : CODE } & \text { CRWS } & \text { FR\# } & \text { YMIN } & \text { YMAX } & \text { HF } & \text { HO } & \text { VHD } & \text { EGL } & \text { WSEL } \\ \text { EXIT3:XS } & 498.04 & 0.84 & 493.32 & 511.76 * * * * * * * * * * * & 0.95 & 499.28 & 498.33 \\ \text { FULV1:FV } & * * * * * * * & 0.54 & 493.32 & 511.76 & 0.52 & 0.00 & 0.52 & 499.79 & 499.27 \\ \text { DSBRG : BR } & 499.22 & 0.56 & 490.30 & 502.66 * * * * * * * * * * * & 1.63 & 504.29 & 502.66 \\ \text { RRWAY:RG } & * * * * * * * * * * * * * * * & 507.51 & 507.67 * * * * * * * * * * * * * * * * * * * * * * * * * * * * * \\ \text { EXIT2:AS } & 498.00 & 0.13 & 493.28 & 511.72 & 0.09 & 0.39 & 0.06 & 505.27 & 505.21 \\ \text { EXITX:XS } & * * * * * * * * & 0.28 & 494.70 & 512.97 & 0.41 & 0.11 & 0.28 & 505.79 & 505.50 \\ \text { FULLV:FV } & * * * * * * * * & 0.28 & 494.73 & 513.00 & 0.15 & 0.00 & 0.27 & 505.95 & 505.67 \\ \text { BRIDG:BR } & 501.92 & 0.47 & 491.86 & 507.07 * * * * * * * * * * * & 0.91 & 507.57 & 506.66 \\ \text { RDWAY:RG } & * * * * * * * * * * * * * * * * & 507.22 & 511.85 & 0.07 * * * * * * & 0.19 & 508.02 & 507.88 \\ \text { APPRO:AS } & 502.00 & 0.26 & 494.01 & 511.83 & 0.20 & 0.16 & 0.19 & 508.09 & 507.90\end{array}$


WSPRO OUTPUT FILE (continued)

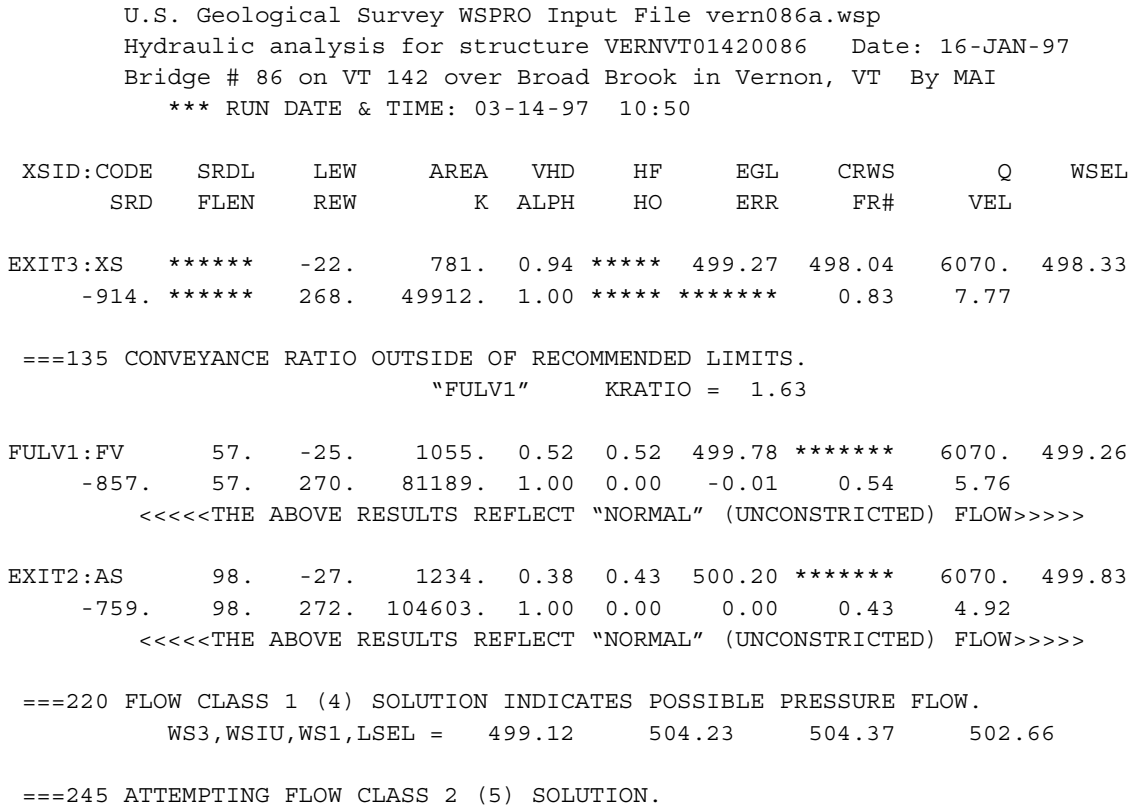




\section{WSPRO OUTPUT FILE (continued)}

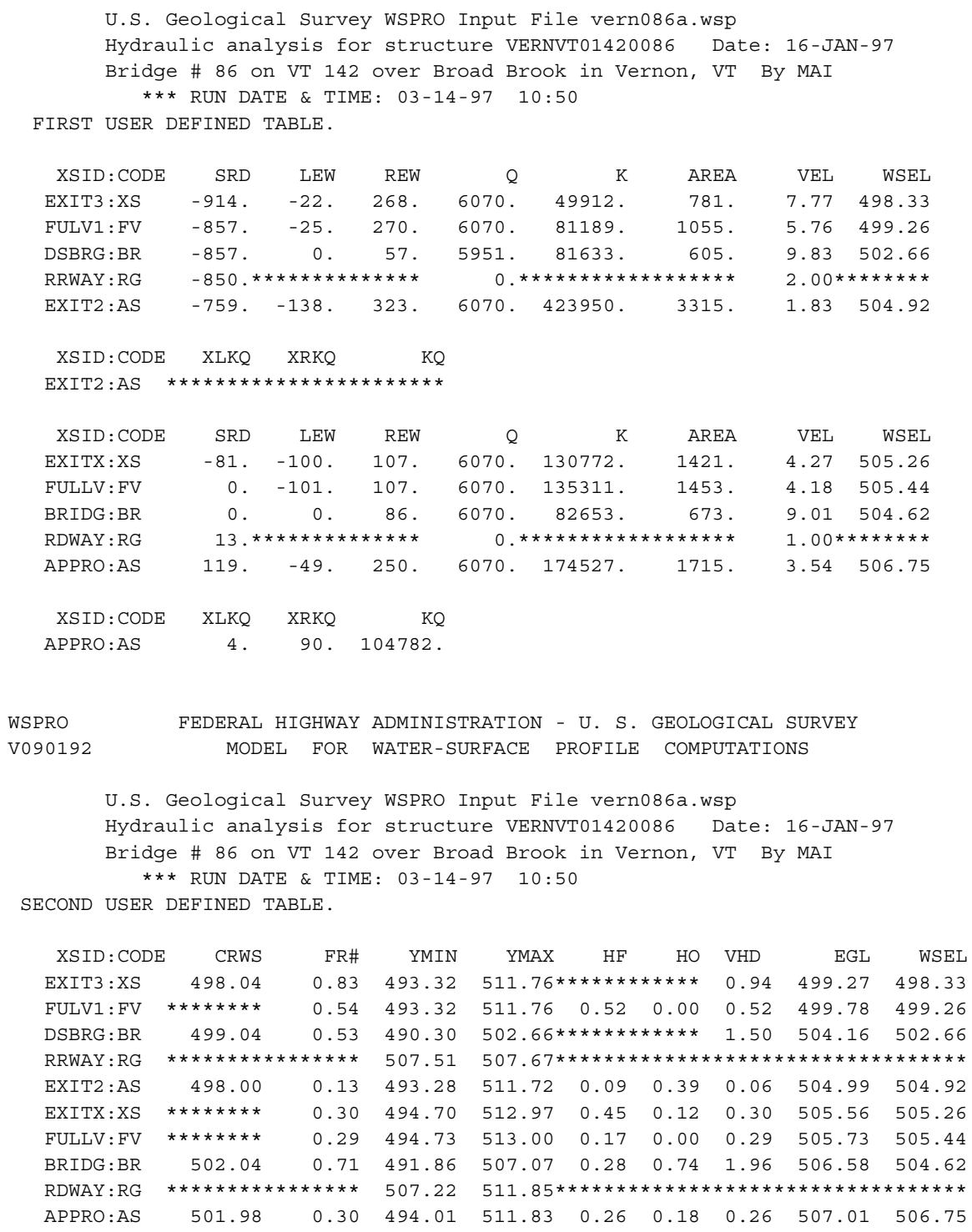




\section{APPENDIX C:}

\section{BED-MATERIAL PARTICLE-SIZE DISTRIBUTION}




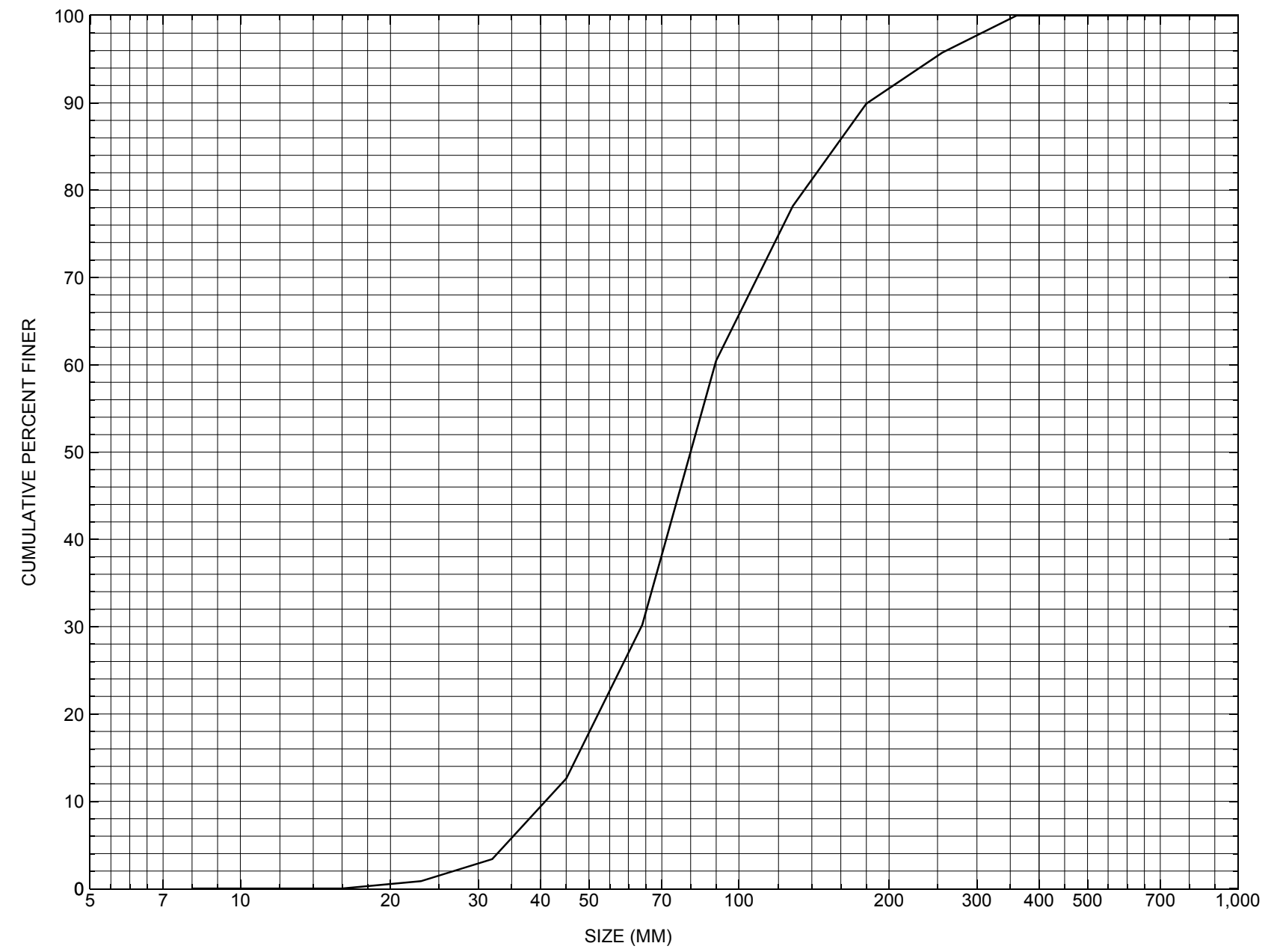

Appendix C. Bed material particle-size distribution for a pebble count in the channel approach of structure VERNVT01420086, in Vernon, Vermont. 


\section{APPENDIX D: \\ HISTORICAL DATA FORM}




\section{Structure Number VERNVT01420086}

\section{General Location Descriptive}

Data collected by (First Initial, Full last name) $\mathbf{E}$. BOEHMLER

Date $(M M / D D / Y Y) \_\mathbf{0 3} / \underline{\mathbf{3 0} /} \mathbf{9 5}$

Highway District Number (I - 2; nn) $\mathbf{0 2}$

Town (FIPS place code; I - 4; nnnnn) $\mathbf{7 4 8 0 0}$

Waterway (I - 6) BROAD BROOK

Route Number VT142

Topographic Map Brattleboro

Latitude (I - 16; nnnn.n) $\mathbf{4 2 4 9 1}$
County (FIPS county code; I - 3; nnn)

Mile marker (I - 11; nnn.nnn) $\mathbf{0 0 8 3 0 0}$

Road Name (I - 7): -

Vicinity (I - 9) 2.9 MI S JCT. U.S.5

Hydrologic Unit Code: $\mathbf{0 1 0 8 0 1 0 4}$

Longitude (i - 17; nnnnn.n) $\mathbf{7 2 3 2 8}$

\section{Select Federal Inventory Codes}

FHWA Structure Number $(I$ - 8) $\mathbf{2 0 0 1 0 9 0 0 0 6 1 3 1 8}$

Maintenance responsibility $(I-21 ; n n) \quad 01$

Year built (I - 27; YYYY) 1930

Average daily traffic, ADT (I - 29; nnnnnn) 002463

Year of ADT (I - 30; YY) $\mathbf{9 2}$

Opening skew to Roadway $(I-34 ; n n) \quad \mathbf{0 0}$

Operational status $(I-41 ; X) \underline{\mathbf{A}}$

Structure type (I - 43; nnn) $\mathbf{3 0 2}$

Approach span structure type $(I-44 ; n n n) \quad \mathbf{0 0 0}$

Number of spans (I - 45; nnn) $\underline{\mathbf{0 0 2}}$

Number of approach spans (I - 46; nnnn) $\mathbf{0 0 0 0}$

Comments:

The structural inspection report indicates the structure is a two span, steel beam type bridge. Both concrete abutments and the wingwalls have very minor cracks and stains reported. The pier is solid concrete with very minor cracks, stains and spalls noted. There is some good stone riprap in front of both abutments. The waterway takes a moderate turn through the structure, and the majority of flow is beneath the left span. The Connecticut River is just downstream. The streambed consists of silts and sands. There is a sand point bar with vegetation growth just upstream of the pier. There are a few small logs and other debris wedged on the upstream end of the pier. There may be minor scour at the pier nose. The abutment and pier footings are not in view.
Maximum span length (I - 48; nnnn) $\underline{\mathbf{0 0 4 7}}$

Structure length (I - 49; nnnnnn) $\underline{000098}$

Deck Width (I - 52; nn.n) 245

Channel \& Protection $(I-61 ; n) \underline{6}$

Waterway adequacy $(I-71 ; n) \underline{6}$

Underwater Inspection Frequency $(I-92 B ; X Y Y) \_$N

Year Reconstructed (I - 106) $\mathbf{0 0 0 0}$

Clear span (nnn.n ft) $\mathbf{0 4 5 . 0}$

Vertical clearance from streambed (nnn.n ft) $\underline{\mathbf{0 1 0 . 5}}$

Waterway of full opening $\left(n n n . n t^{2}\right) \quad \mathbf{4 7 2 . 5}$ 


\section{Bridge Hydrologic Data}

Is there hydrologic data available? $\underline{\mathbf{N}}$ if No, type ctrl-n $h \quad$ VTAOT Drainage area $\left(m i^{2}\right)$ : -

Terrain character:

Stream character \& type: -

Streambed material: Silt, gravel, some boulders

Discharge Data (cfs): $\quad \mathrm{Q}_{2.33}$

$$
\mathrm{Q}_{50}-
$$

Record flood date $(M M / D D / Y Y):-$

$\begin{array}{ll}Q_{10} \_- & Q_{25}- \\ Q_{100 \_-} & Q_{500 \_}-\end{array}$

Water surface elevation $(f t):-$

Estimated Discharge (cfs): Velocity at $\mathrm{Q}-$ $(\mathrm{ft} / \mathrm{s}):$

Ice conditions (Heavy, Moderate, Light) : -

Debris (Heavy, Moderate, Light):

The stage increases to maximum highwater elevation (Rapidly, Not rapidly):

The stream response is (Flashy, Not flashy):

Describe any significant site conditions upstream or downstream that may influence the stream's stage: This brook enters the Connecticut River just downstream from this bridge site.

Watershed storage area (in percent): - $\%$

The watershed storage area is: - (1-mainly at the headwaters; 2- uniformly distributed; 3-immediatly upstream oi the site)

Water Surface Elevation Estimates for Existing Structure:

\begin{tabular}{|l|l|l|l|l|l|}
\hline Peak discharge frequency & $Q_{2.33}$ & $Q_{10}$ & $Q_{25}$ & $Q_{50}$ & $Q_{100}$ \\
Water surface elevation (ft)) & - & - & - & - & - \\
Velocity (ft/sec) & - & - & - & - & - \\
\hline
\end{tabular}

Long term stream bed changes: -

Is the roadway overtopped below the $Q_{100}$ ? (Yes, No, Unknown): Frequency: -

Relief Elevation $(f t)$ :

Discharge over roadway at $Q_{100}\left(f^{3} / \mathrm{sec}\right)$ :

Are there other structures nearby? (Yes, No, Unknown): If No or Unknown, type ctrl-n os Upstream distance (miles): Town: Year Built:

Highway No. : Structure No. : -

Clear span $(f t)$ : Clear Height (ft): Full Waterway $\left(f^{2}\right)$ : 
Downstream distance (miles): Town: Year Built:

Highway No. : Structure No. : Structure Type:

Clear span $(f t):$ Clear Height $(f t)$ : Full Waterway $\left(f^{2}\right):$

Comments:

\section{USGS Watershed Data}

Watershed Hydrographic Data

Drainage area $(D A) \stackrel{23.702}{\mathrm{mi}^{2}}$

Watershed storage (ST) $\quad .05$ $\mathrm{mi}^{2} \quad$ Lake and pond area .012 $\mathrm{mi}^{2}$

Bridge site elevation 227.7 $\mathrm{ft}$ $\%$

Main channel length 6.954 mi $10 \%$ channel length elevation 295.3 $\mathrm{ft} \quad 85 \%$ channel length elevation $\mathrm{ft}$

Main channel slope

(S) $\mathbf{5 6 . 6 7}$
$\mathrm{ft} / \mathrm{mi}$

Watershed Precipitation Data

Average site precipitation in Average headwater precipitation in

Maximum 2yr-24hr precipitation event $(124,2)$ in

Average seasonal snowfall (Sn) $\mathrm{ft}$ 


\section{Bridge Plan Data}

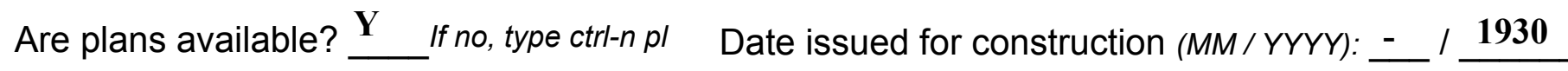
Project Number Minimum channel bed elevation: $\mathbf{1 8 8 . 0}$

Low superstructure elevation: USLAB DSLAB USRAB DSRAB Benchmark location description:

BM\#1: [spike in the root or trunk of] an 8 inch elm tree, about 30 feet right bankward of the right abutment and 45 feet right of the roadway centerline, elevation 200.0 .

Reference Point (MSL, Arbitrary, Other): Arbitrary Datum (NAD27, NAD83, Other): Arbitrary Foundation Type: 1 (1-Spreadfooting; 2-Pile; 3- Gravity; 4-Unknown)

If 1: Footing Thickness $\mathbf{2} \quad$ Footing bottom elevation: $\underline{\mathbf{1 8 6 . 0}}$

If 2: Pile Type:___ (1-Wood; 2-Steel or metal; 3-Concrete) Approximate pile driven length:

If 3: Footing bottom elevation:

Is boring information available? $\underline{\mathbf{Y}}$ If no, type ctrl- $n$ bi Number of borings taken: $\underline{\mathbf{2}}$

Foundation Material Type: 1 (1-regolith, 2-bedrock, 3-unknown)

Briefly describe material at foundation bottom elevation or around piles:

The foundation material is a coarse sand and gravel as stated in plans

Comments:

The plans could not be found on March 30, 1995. 


\section{Cross-sectional Data}

Is cross-sectional data available? $\underline{\mathbf{Y}}$ If no, type ctrl-n xs

Source (FEMA, VTAOT, Other)? VTAOT

Comments: Some cross sections are available. Orientation of the cross sections is inconsistent with any cross section data surveyed for this study and is not comparable. Data was not retrieved.

\begin{tabular}{|l|l|l|l|l|l|l|l|l|l|l|l|}
\hline Station & - & - & - & - & - & - & - & - & - & - & - \\
\hline Feature & - & - & - & - & - & - & - & - & - & - & - \\
\hline $\begin{array}{l}\text { Low cord } \\
\text { elevation }\end{array}$ & - & - & - & - & - & - & - & - & - & - & - \\
\hline $\begin{array}{l}\text { Bed } \\
\text { elevation }\end{array}$ & - & - & - & - & - & - & - & - & - & - & - \\
\hline $\begin{array}{l}\text { Low cord to } \\
\text { bed length }\end{array}$ & - & - & - & - & - & - & - & - & - & - & - \\
\hline Station & - & - & - & - & - & - & - & - & - & - & - \\
\hline Feature & - & - & - & - & - & - & - & - & - & - & - \\
\hline $\begin{array}{l}\text { Low cord } \\
\text { elevation }\end{array}$ & - & - & - & - & - & - & - & - & - & - & - \\
\hline $\begin{array}{l}\text { Bed } \\
\text { elevation }\end{array}$ & - & - & - & - & - & - & - & - & - & - & - \\
\hline $\begin{array}{l}\text { Low cord to } \\
\text { bed length }\end{array}$ & - & - & - & - & - & - & - & - & - & - & - \\
\hline
\end{tabular}

Source (FEMA, VTAOT, Other)?

Comments: -

\begin{tabular}{|l|l|l|l|l|l|l|l|l|l|l|l|}
\hline Station & - & - & - & - & - & - & - & - & - & - & - \\
\hline Feature & - & - & - & - & - & - & - & - & - & - & - \\
\hline $\begin{array}{l}\text { Low cord } \\
\text { elevation }\end{array}$ & - & - & - & - & - & - & - & - & - & - & - \\
\hline $\begin{array}{l}\text { Bed } \\
\text { elevation }\end{array}$ & - & - & - & - & - & - & - & - & - & - & - \\
\hline $\begin{array}{l}\text { Low cord to } \\
\text { bed length }\end{array}$ & - & - & - & - & - & - & - & - & - & - & - \\
\hline Station & - & - & - & - & - & - & - & - & - & - & - \\
\hline Feature & - & - & - & - & - & - & - & - & - & - & - \\
\hline $\begin{array}{l}\text { Low cord } \\
\text { elevation }\end{array}$ & - & - & - & - & - & - & - & - & - & - & - \\
\hline $\begin{array}{l}\text { Bed } \\
\text { elevation }\end{array}$ & - & - & - & - & - & - & - & - & - & - & - \\
\hline $\begin{array}{l}\text { Low cord to } \\
\text { bed length }\end{array}$ & - & - & - & - & - & - & - & - & - & - & \\
\hline
\end{tabular}




\section{APPENDIX E: \\ LEVEL I DATA FORM}


U. S. Geological Survey

Bridge Field Data Collection and Processing Form

Qa/Qc Check by: RB Date: 1 10/10/96

\section{Structure Number VERNVT01420086}

Computerized by: $\mathbf{R B}$ Date: $1 \mathbf{1 0 / 3 1 / 9 6}$

Reviewd by:

MAI Date: $\underline{03 / 26 / 97}$

\section{A. General Location Descriptive}

1. Data collected by (First Initial, Full last name) R. FLYNN

2. Highway District Number $\mathbf{0 2}$

Date $(M M / D D / Y Y) \underline{08} / \underline{14} / \underline{1996}$

County 025 WINDHAM

Mile marker 008300

Waterway (I - 6) BROAD BROOK

Route Number VT142

Town 74800 VERNON

Road Name -

Hydrologic Unit Code: $\mathbf{0 1 0 8 0 1 0 4}$

3. Descriptive comments:

Located 2.9 miles south of the junction with US 5.

\section{B. Bridge Deck Observations}
4. Surface cover... LBUS 6
RBUS 6
LBDS 7
RBDS 6
Overall 6

(2b us, ds,lb,rb: 1- Urban; 2- Suburban; 3- Row crops; 4- Pasture; 5- Shrub- and brushland; 6- Forest; 7- Wetland)
5. Ambient water surface... US 1
UB 1
DS 1
(1- pool; 2- riffle)

6. Bridge structure type 2 (1- single span; 2- multiple span; 3- single arch; 4- multiple arch; 5- cylindrical culvert; 6- box culvert; or 7- other)
7. Bridge length $\mathbf{9 8}$
(feet)
Span length $\underline{47}$
(feet)
Bridge width 24.5 (feet)

\section{Road approach to bridge:}
8. LB 1 RB $\underline{0}$
( 0 even, 1- lower, 2- higher)
9. LB
RB 1
(1- Paved, 2- Not paved)

10. Embankment slope (run / rise in feet / foot)

$$
\text { US left }
$$

1.6:1

US right

3.1:1

\begin{tabular}{|c|c|c|c|c|}
\cline { 2 - 5 } & \multicolumn{2}{|c|}{ Protection } & \multirow{2}{*}{ 13.Erosion } & 14.Severity \\
\cline { 2 - 5 } LBUS & 11.Type & 12.Cond. & $\mathbf{1}$ & $\underline{\mathbf{2}}$ \\
\cline { 2 - 5 } RBUS & $\mathbf{1}$ & - & $\underline{\mathbf{3}}$ & $\mathbf{1}$ \\
\hline RBDS & $\mathbf{1}$ & $\underline{\mathbf{1}}$ & $\underline{\mathbf{3}}$ \\
\hline LBDS & $\mathbf{1}$ & $\mathbf{1}$ & $\mathbf{3}$ \\
\hline
\end{tabular}

Bank protection types: 0 - none; 1- $<12$ inches;

2- < 36 inches; 3- < 48 inches;

4- < 60 inches; 5- wall / artificial levee

Bank protection conditions: 1- good; 2- slumped;

3- eroded; 4- failed

Erosion: 0 - none; 1- channel erosion; 2 -

road wash; 3- both; 4- other

Erosion Severity: 0 - none; 1- slight; 2- moderate; 3- severe

\section{Channel approach to bridge (BF):}

15. Angle of approach: $\mathbf{2 0}$

16. Bridge skew: $\mathbf{3 0}$

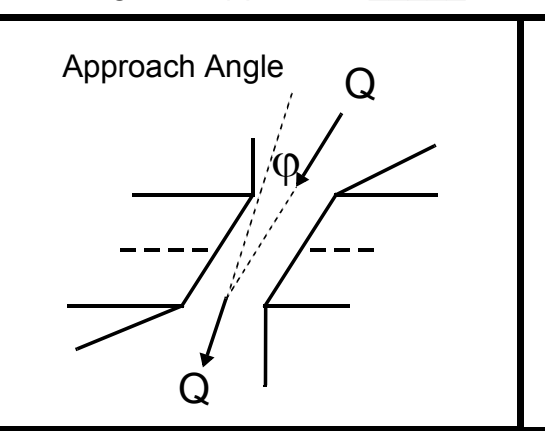

17. Channel impact zone 1:

Where? LB $(L B, R B)$ Bridge Skew Angle

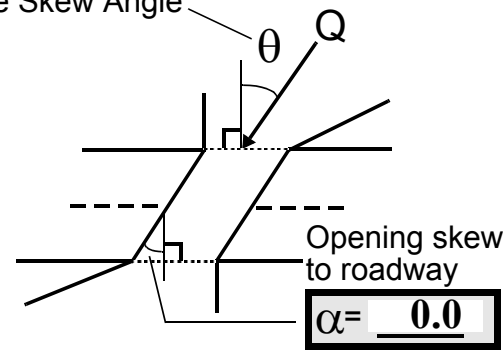

Range? 0 feet US (US,

Channel impact zone 2:

Where? RB (LB, RB)

Exist? $\mathbf{Y}(Y$ or $N)$

Range? $\underline{\mathbf{0}}$ feet $\underline{\mathbf{U S}}$ (US, UB, DS) to $\underline{\mathbf{2 5 0}}$ feet $\underline{\mathbf{D S}}$

Impact Severity: 0- none to very slight; 1-Slight; 2- Moderate; 3- Severe 
18. Bridge Type: $\mathbf{3}$

1a- Vertical abutments with wingwalls

1 b- Vertical abutments without wingwalls

2- Vertical abutments and wingwalls, sloping embankment Wingwalls perpendicular to abut. face

3- Spill through abutments

4- Sloping embankment, vertical wingwalls and abutments

Wingwall angle less than $90^{\circ}$.

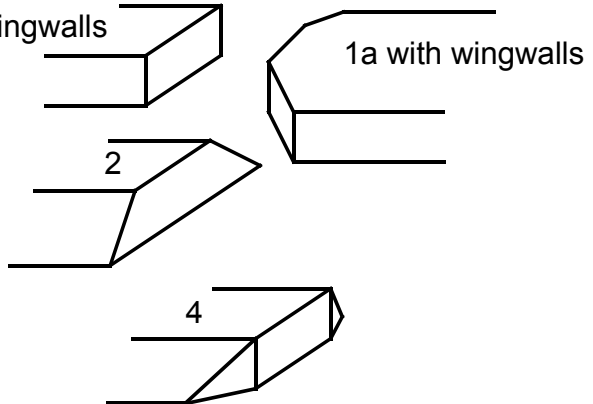

19. Bridge Deck Comments (surface cover variations, measured bridge and span lengths, bridge type variations, approach overflow width, etc.)

7. Values are from the VT AOT files. Measured bridge length is $97.8 \mathrm{ft}$. and the bridge width is $24.5 \mathrm{ft}$.

4. There are some small cottages on the US right bank.

18. The bridge has spill-through slopes consisting of sand and gravel with type 2 protection along the entire base length of the toe of each slope. There is one pier in the center of the bridge.

\section{Upstream Channel Assessment}

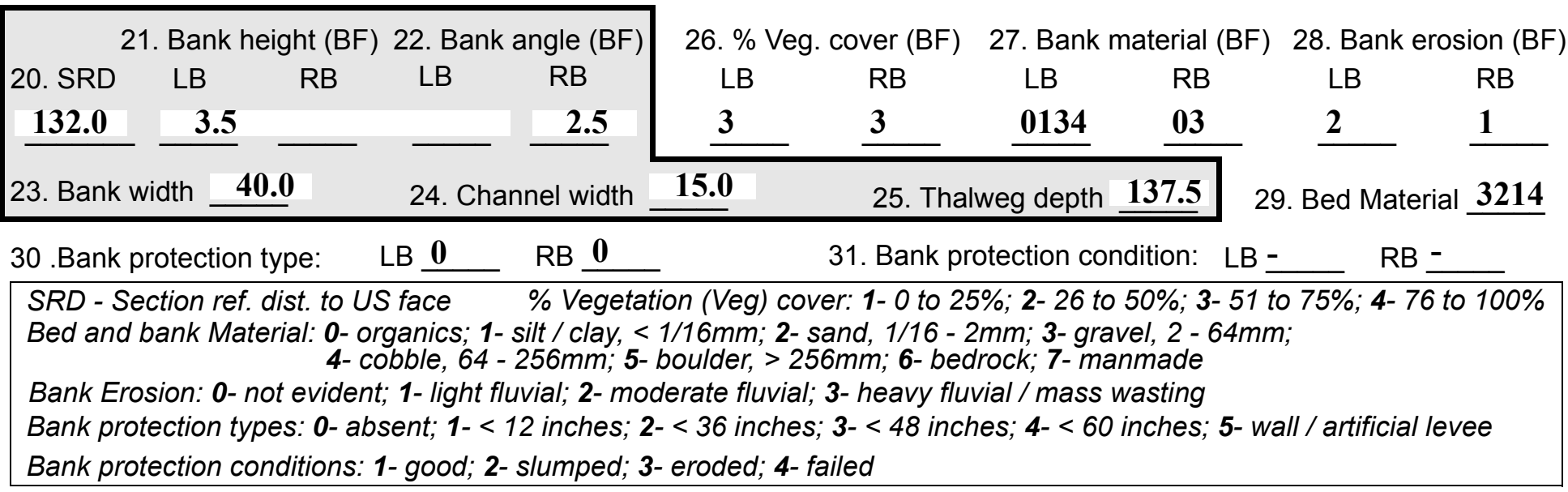

32. Comments (bank material variation, minor inflows, protection extent, etc.):

29. The bed material is predominantly gravel and boulders greater than $300 \mathrm{ft}$ US of the approach. There was an extensive amount of sand and silt intermixed with the gravel and cobble. 
36. Point bar extent: 12 feet $\underline{\mathbf{U S}}$ (US, UB) to $\underline{\mathbf{2 1 0}}$ feet $\underline{\mathbf{U S}}$ (US, UB, DS) positioned $\underline{\mathbf{5 0}} \%$ LB to $\underline{\mathbf{0}} \%$ RB

37. Material: $\mathbf{0 2 3 4}$

38. Point or side bar comments (Circle Point or Side; Note additional bars, material variation, status, etc.):

This is an old bar with vegetation and small trees. Another point bar is along the left bank from $210 \mathrm{ft}$. US to $350 \mathrm{ft}$. US. It is comprised of organics, sand, gravel and cobble. A third point bar is located on the right bank from $300 \mathrm{ft}$. US to $400 \mathrm{ft}$. US. It is comprised of gravel, sand and cobbles.

39. Is a cut-bank present? $\mathbf{Y}$ ( $Y$ or if $N$ type ctrl-n $c b)$

41. Mid-bank distance: 100

42. Cut bank extent: $\underline{\mathbf{2 1 0}}$ feet $\underline{\mathrm{US}}$ (US, UB) to $\underline{\mathbf{0}}$

40. Where? LB (LB or RB)

43. Bank damage: 1

(1- eroded and/or creep; 2- slip failure; 3- block failure)

44. Cut bank comments (eg. additional cut banks, protection condition, etc.):

Tree roots are exposed and several trees are in danger of falling into the river.

\section{Is channel scour present? $\mathbf{Y}$ ( $Y$ or if $N$ type ctrl-n cs)}

47. Scour dimensions: Length 195

Width 20

Depth : 4

46. Mid-scour distance: $\mathbf{5 5}$

48. Scour comments (eg. additional scour areas, local scouring process, etc.):

Scour is evident from $20 \mathrm{ft}$. DS to $150 \mathrm{ft}$. US. Another scour hole is evident US and adjacent to the point bar from $190 \mathrm{ft}$. US to $225 \mathrm{ft}$. US. It is $35 \mathrm{ft}$. long, $20 \mathrm{ft}$. wide, and $2 \mathrm{ft}$. deep. It is positioned from $50 \% \mathrm{LB}$ to $25 \%$ RB.

49. Are there major confluences? $\mathbf{N}$

51. Confluence 1: Distance -

Confluence 2: Distance -

54. Confluence comments (eg. confluence name):

NO MAJOR CONFLUENCES
( $Y$ or if $N$ type ctrl-n mc)

52. Enters on -

Enters on ( $L B$ or $R B)$ (LB or $R B)$
50. How many? -

53. Type(1- perennial; 2- ephemeral)

Type (1-perennial; 2-ephemeral)

NO MAJOR C

\section{Under Bridge Channel Assessment}

55. Channel restraint (BF)? LB 2

56. Height (BF)
LB RB AB
$\mathbf{1 2 2 . 0}$
58. Bank width (BF) -

59. Channel width $(A m b)$

61. Material (BF)

LB RB

$\underline{2} \quad \underline{7}$

Angle (BF)

4.0

Bed and bank Material: 0- organics; 1- silt / clay, < 1/16mm; 2- sand, 1/16 - 2mm; 3- gravel, 2 - 64mm; 4- cobble, 64 - 256mm; 5- boulder, > 256mm; 6- bedrock; 7- manmade

Bank Erosion: 0- not evident; 1- light fluvial; 2- moderate fluvial; 3- heavy fluvial / mass wasting

64. Comments (bank material variation, minor inflows, protection extent, etc.):

3214

The protection under the bridge acts like a spill through. In front of the abutments and behind the protection are sand and gravel banks that have moderate fluvial erosion. 
65. Debris and Ice Is there debris accumulation?

$(Y$ or $N)$ 66. Where? $\underline{Y}$

(1- Upstream; 2- At bridge; 3- Both)

67. Debris Potential $\underline{3}$

( 1-Low; 2- Moderate; 3- High)

68. Capture Efficiency 3

(1-Low; 2- Moderate; 3- High)

69. Is there evidence of ice build-up? 3 (Y or $N)$

Ice Blockage Potential $\underline{\mathbf{Y}}$

(1-Low; 2- Moderate; 3- High)

70. Debris and Ice Comments:

3

There is debris accumulation along the center pier, including an 18 in. diameter log. Debris has also accumulated US of the point bar at $210 \mathrm{ft}$. US. Ice build up is evident by scarring of the tree trunks.

\begin{tabular}{|l|c|c|c|c|c|c|c|c|}
\hline Abutments & $\begin{array}{c}\text { 71. Attack } \\
\angle \text { (BF) }\end{array}$ & $\begin{array}{c}\text { 72. Slope } \angle \\
\text { (Qmax) }\end{array}$ & $\begin{array}{c}\text { 73. Toe } \\
\text { loc. (BF) }\end{array}$ & $\begin{array}{c}\text { 74. Scour } \\
\text { Condition }\end{array}$ & $\begin{array}{c}75 . \text { Scour } \\
\text { depth }\end{array}$ & $\begin{array}{c}\text { 76. Exposure } \\
\text { depth }\end{array}$ & 77. Material & 78. Length \\
\hline LABUT & & $\mathbf{0}$ & $\mathbf{9 0}$ & $\mathbf{2}$ & $\mathbf{1}$ & $\mathbf{2}$ & $\mathbf{0}$ & $\mathbf{9 0 . 0}$ \\
\hline RABUT & $\mathbf{1}$ & $\mathbf{2 0}$ & $\mathbf{9 0}$ & & & $\mathbf{2}$ & $\mathbf{1}$ & $\mathbf{9 3 . 0}$ \\
\hline
\end{tabular}

Pushed: $L B$ or RB

Toe Location (Loc.): 0- even, 1- set back, 2- protrudes

Scour cond.: 0- not evident; 1- evident (comment); 2- footing exposed; 3-undermined footing; 4- piling exposed; 5- settled; 6- failed

Materials: 1- Concrete; 2- Stone masonry or drywall; 3- steel or metal; 4- wood

79. Abutment comments (eg. undermined penetration, unusual scour processes, debris, etc.):

2

0

1

The abutments are protected by "spill-through" slopes at a 45 degree angle from the bed. The stone protection at the base of these banks is $4 \mathrm{ft}$. high.

80. Wingwalls:

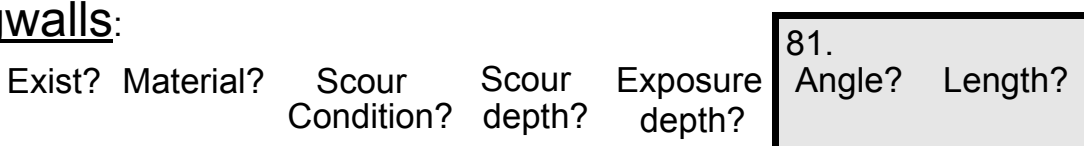

USLWW:

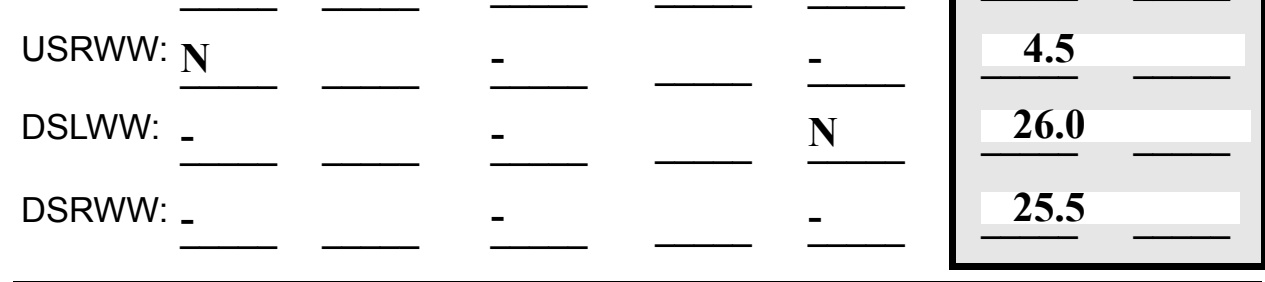

Wingwall materials: 1- Concrete; 2- Stone masonry or drywall; 3- steel or metal; 4- wood

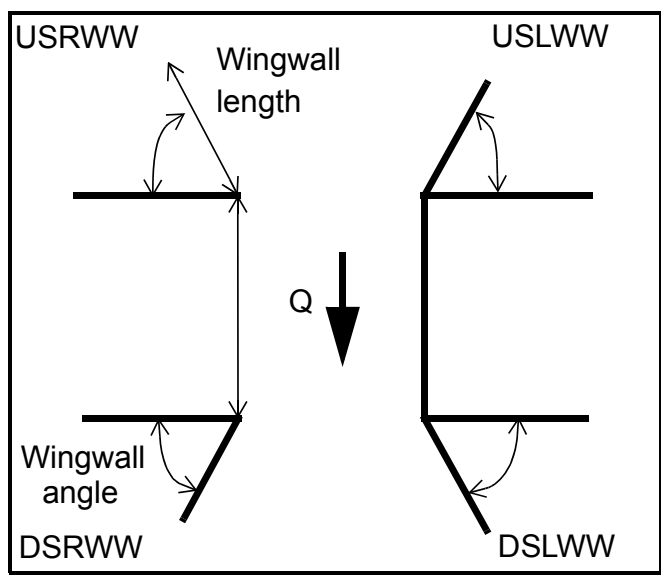

82. Bank / Bridge Protection:

\begin{tabular}{|l|l|l|l|l|l|l|l|l|}
\hline Location & USLWW & USRWW & LABUT & RABUT & LB & RB & DSLWW & DSRWW \\
\hline Type & - & - & N & - & - & - & - & - \\
\hline Condition & N & - & - & - & - & - & - & - \\
\hline Extent & - & - & - & - & - & $\mathbf{0}$ & $\mathbf{0}$ & $\mathbf{2}$ \\
\hline
\end{tabular}

Bank / Bridge protection types: 0- absent; 1- < 12 inches; 2- < 36 inches; 3- < 48 inches; 4- < 60 inches; 
83. Wingwall and protection comments (eg. undermined penetration, unusual scour processes, etc.):

2

1

2

2

1

\section{Piers:}

84. Are there piers? 82. ( $Y$ or if $N$ type ctrl-n pr)

\begin{tabular}{|l|l|l|l|l|l|l|l|}
\hline \multirow{2}{*}{$\begin{array}{l}85 . \\
\text { Pier no. }\end{array}$} & \multicolumn{3}{|c|}{ width (w) feet } & \multicolumn{3}{c|}{ elevation (e) feet } \\
\cline { 2 - 9 } & w1 & w2 & w3 & e@w1 & e@w2 & e@w3 \\
\hline Pier 1 & - & - & - & - & - & - \\
\hline Pier 2 & - & $\mathbf{4}$ & $\mathbf{5}$ & - & $\mathbf{5 0 6 . 5}$ & $\mathbf{4 9 2 . 8}$ \\
\hline Pier 3 & - & - & - & - & - & - \\
\hline Pier 4 & - & - & - & - & - & - \\
\hline
\end{tabular}

\begin{tabular}{|l|l|l|l|l|}
\hline Level 1 Pier Descr. & \multicolumn{1}{|c|}{1} & \multicolumn{1}{|c|}{2} & 3 & \multicolumn{1}{|c|}{4} \\
\hline 86. Location (BF) & The left & the & & $\mathbf{1 0}$ \\
\hline 87. Type & and & bank & & RB \\
\hline 88. Material & right & to & & - \\
\hline 89. Shape & bank & the & & $\mathbf{0}$ \\
\hline 90. Inclined? & pro- & abut & & $\mathbf{1}$ \\
\hline 91. Attack $\angle$ (BF) & tec- & ment & Y & $\mathbf{2 - 4}$ \\
\hline 92. Pushed & tion & - & MC & $\mathbf{0 . 5}$ \\
\hline 93. Length (feet) & - & - & - & - \\
\hline 94. \# of piles & does & & M & - \\
\hline 95. Cross-members & not & & $\mathbf{1}$ & - \\
\hline 96. Scour Condition & exte & & $\mathbf{2}$ & - \\
\hline 97. Scour depth & nd & & $\mathbf{1}$ & - \\
\hline 98. Exposure depth & up & & Y & - \\
\hline
\end{tabular}

LFP, LTB, LB, MCL, MCM, MCR, RB, RTB, RFP

1- Solid pier, 2-column, 3- bent

1-Wood; 2- concrete; 3- metal; 4- stone

1- Round; 2- Square; 3- Pointed

Y-yes; $N$ - no

$L B$ or $R B$

0- none; 1- laterals; 2- diagonals; 3- both

0- not evident; 1- evident (comment);

2- footing exposed; 3- piling exposed;

4- undermined footing; 5- settled; 6-failed 
99. Pier comments (eg. undermined penetration, protection and protection extent, unusual scour processes, etc.):

-
-
-
-
-
-
-
-
-

100.

\section{E. Downstream Channel Assessment}

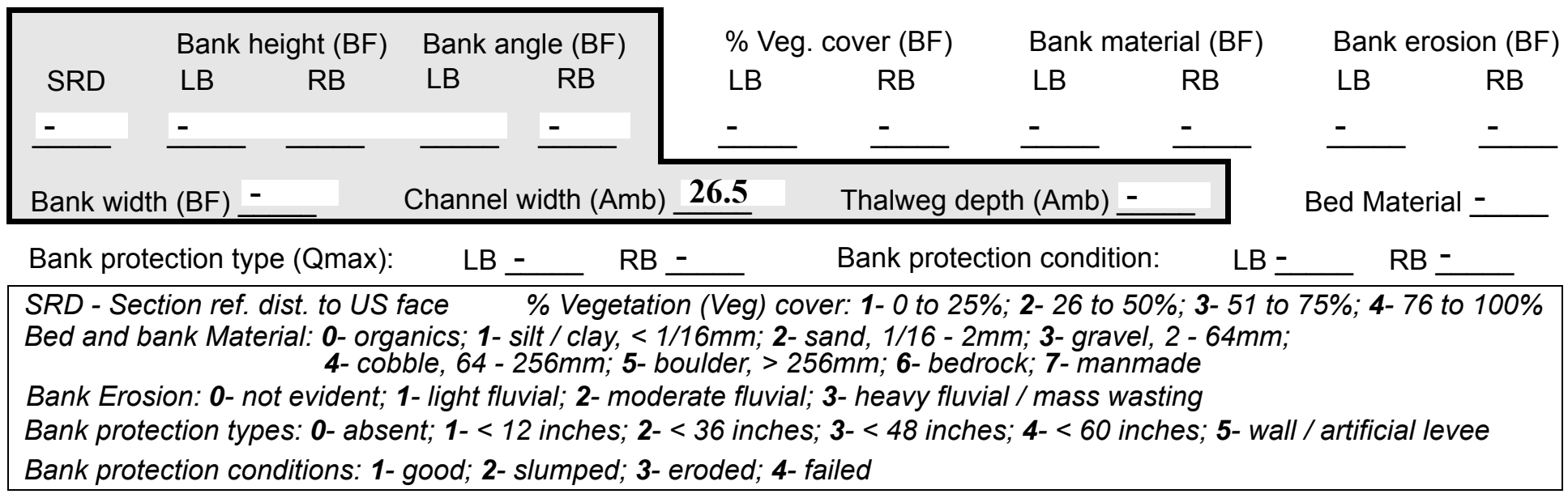

Comments (eg. bank material variation, minor inflows, protection extent, etc.):

-
-
-
-
-
-
-
-
-
-

97. Scour depth is $2 \mathrm{ft}$. adjacent to the pier on the left side and US of the pier face. The scour DS is $4 \mathrm{ft}$. deep with the footing exposed at the DS face of the pier and along the DS half of the left side of the pier. There is debris at the US face of the pier that is adding to the scouring effects toward the left side of the pier. The right side of the pier is filling in adjacent to the pier and scouring is evident at the base of the right abutment protection. The scour is $1 \mathrm{ft}$. deep and $10 \mathrm{ft}$. wide along the length of the right abutment.

\section{Is a drop structure present? ___ ( or N, if N type ctrl-n ds) 102. Distance: _ _ feet}
103. Drop: - feet
104. Structure material:
(1- steel sheet pile; 2- wood pile; 3- concrete; 4- other)

105. Drop structure comments (eg. downstream scour depth): 
106. Point/Side bar present? 12 (Y or N. if N type ctrl-n pb)Mid-bar distance: $\mathbf{0 3}$

Mid-bar width: 2

Point bar extent: 2 feet $\underline{321}$ (US, UB, DS) to $\underline{4}$ feet $\underline{\mathbf{0}}$ (US, UB, DS) positioned $\underline{\mathbf{0}}$ $\%$ LB to $\%$ RB

Material:

Point or side bar comments (Circle Point or Side; note additional bars, material variation, status, etc.):

There is a railroad bridge approximately $650 \mathrm{ft}$. DS of the bridge.

Is a cut-bank present? (Y or if $N$ type ctrl- $n$ cb) Where? (LB or $R B)$

Mid-bank distance:

Cut bank extent: feet (US, UB, DS) to feet (US, UB, DS)

Bank damage: (1- eroded and/or creep; 2- slip failure; 3- block failure)

Cut bank comments (eg. additional cut banks, protection condition, etc.):

$\mathbf{N}$

Is channel scour present? __ (Y or if N type ctrl-n cs) Mid-scour distance: NO

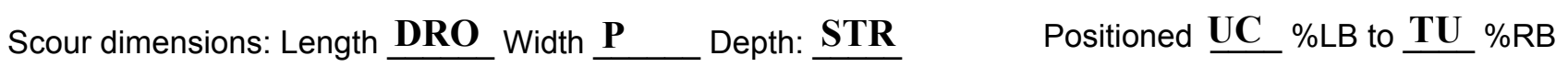
Scour comments (eg. additional scour areas, local scouring process, etc.):

RE

Are there major confluences? Confluence 1: Distance $\mathbf{N}$ Confluence 2: Distance Confluence comments (eg. confluence name): (Y or if $N$ type ctrl-n $m c)$ Enters on $(L B$ or $R B)$ (LB or $R B)$
How many?

Type (1- perennial; 2- ephemeral)

Type (1- perennial; 2- ephemeral)

\section{F. Geomorphic Channel Assessment}

107. Stage of reach evolution -

1- Constructed

2- Stable

3- Aggraded

4- Degraded

5- Laterally unstable

6- Vertically and laterally unstable 
108. Evolution comments (Channel evolution not considering bridge effects; See HEC-20, Figure 1 for geomorphic descriptors):

-

NO POINT BARS

The channel splits $75 \mathrm{ft}$. DS with a large anabranched island in the center of the channel to $400 \mathrm{ft}$. DS.

Y

RB

200

0

DS

400

DS

1 


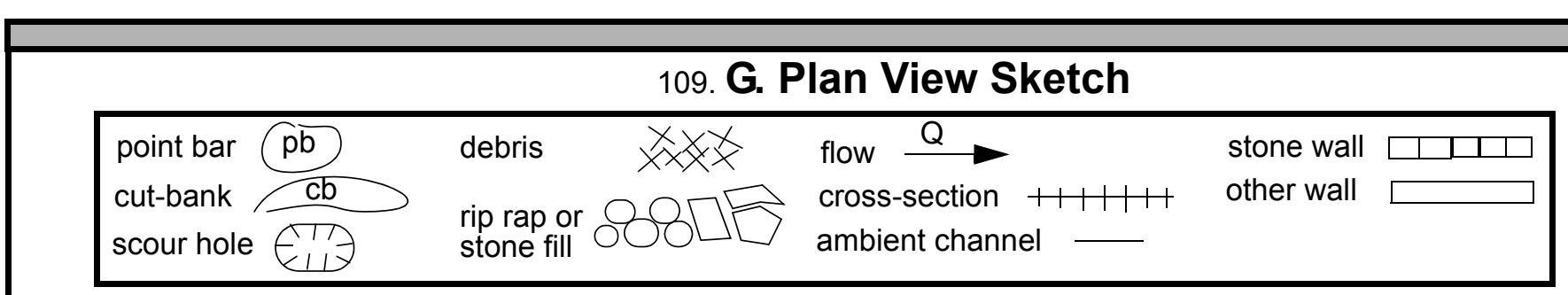

Tr 
APPENDIX F:

SCOUR COMPUTATIONS 


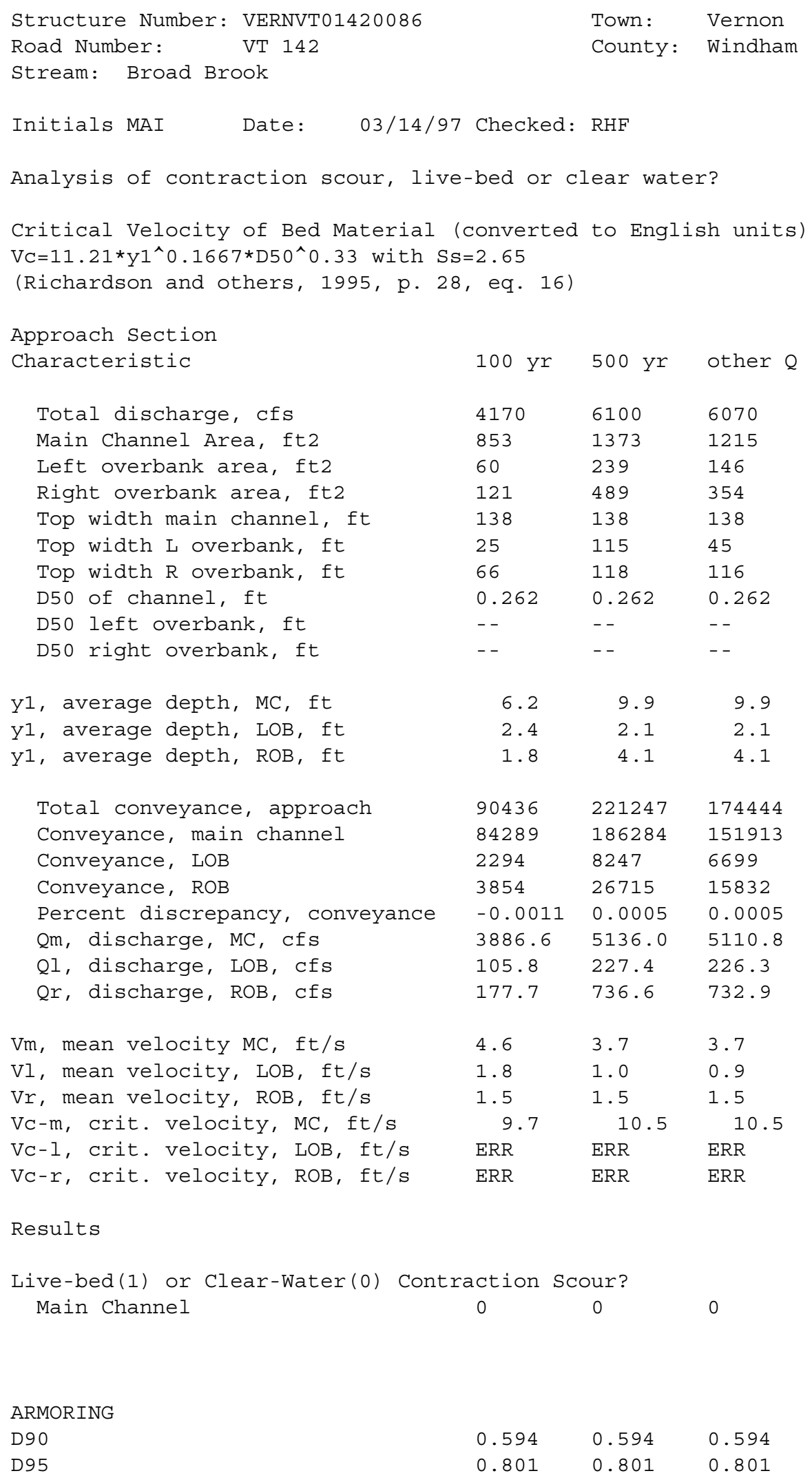


Critical grain size, Dc, ft Decimal-percent coarser than DC Depth to armoring, ft

$\begin{array}{lll}0.2833 & 0.1948 & 0.2783 \\ 0.4317 & 0.7351 & 0.4475 \\ 1.12 & 0.21 & 1.03\end{array}$

Clear water Contraction Scour in MAIN CHANNEL

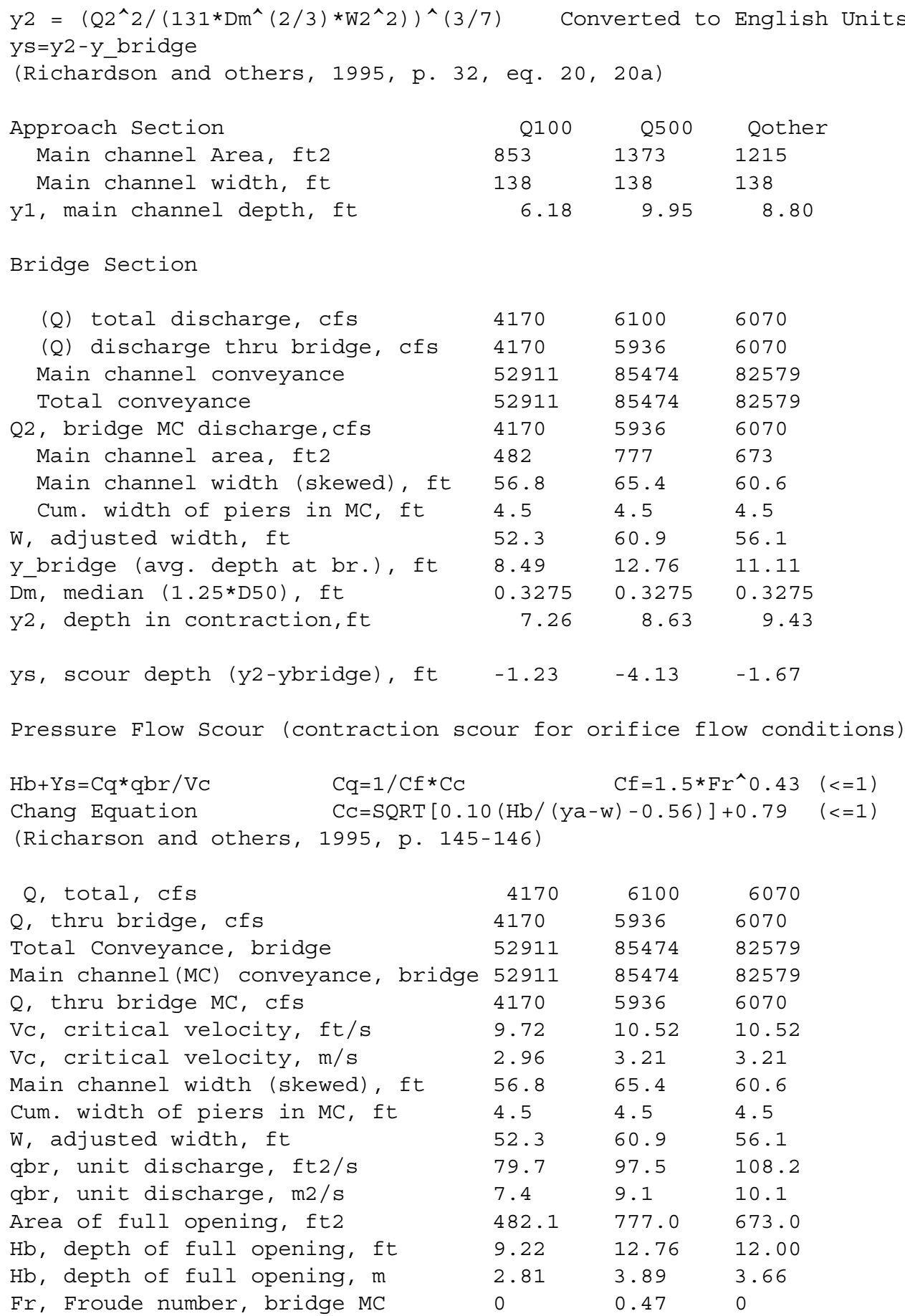




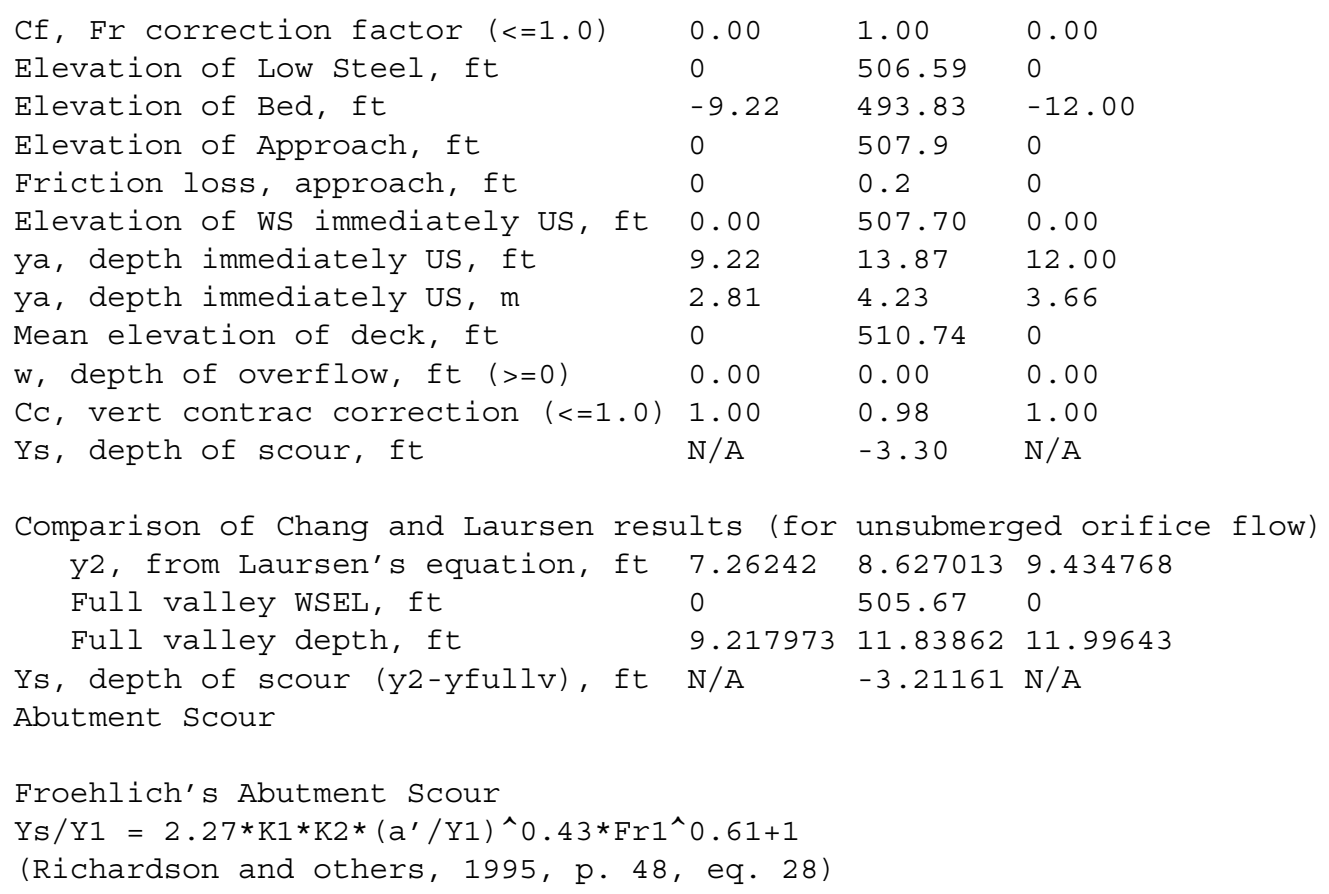




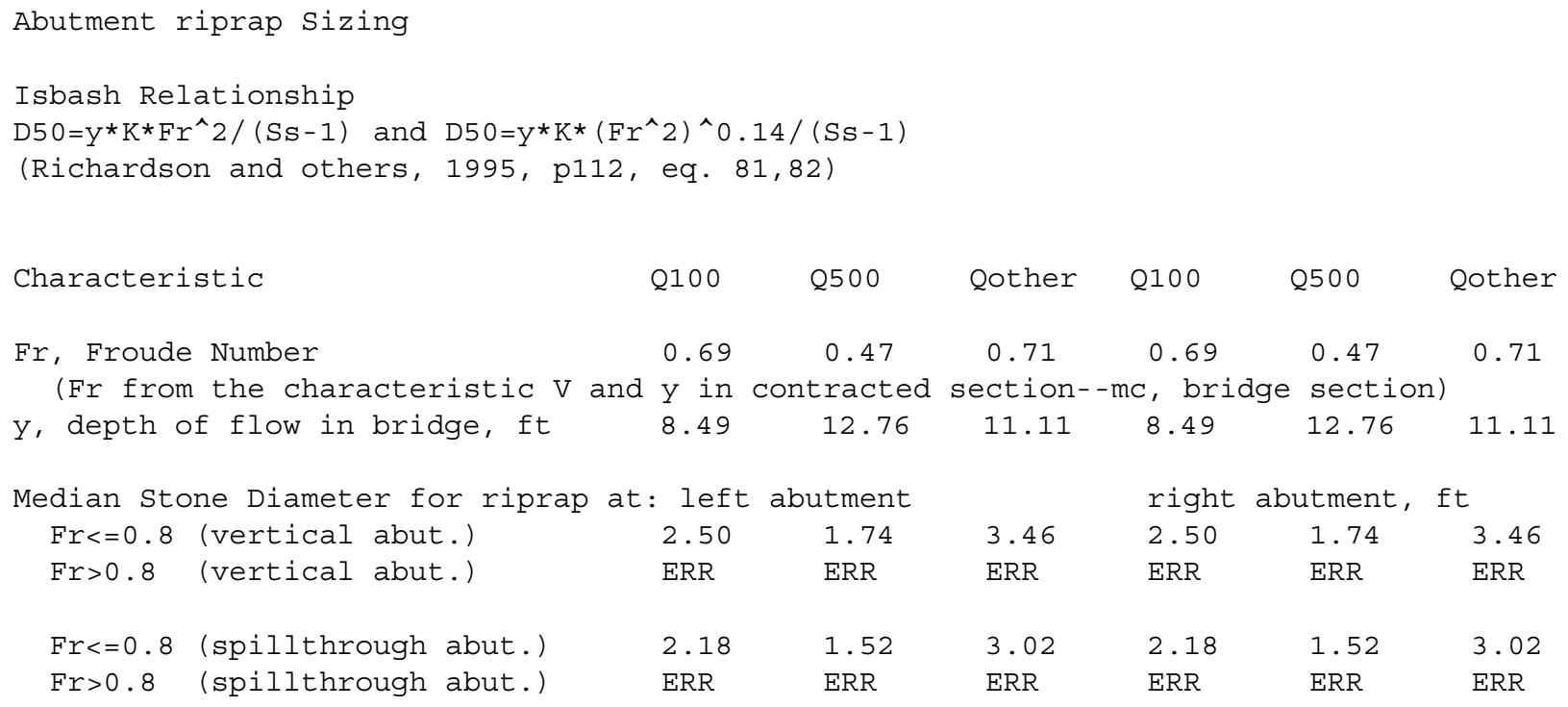




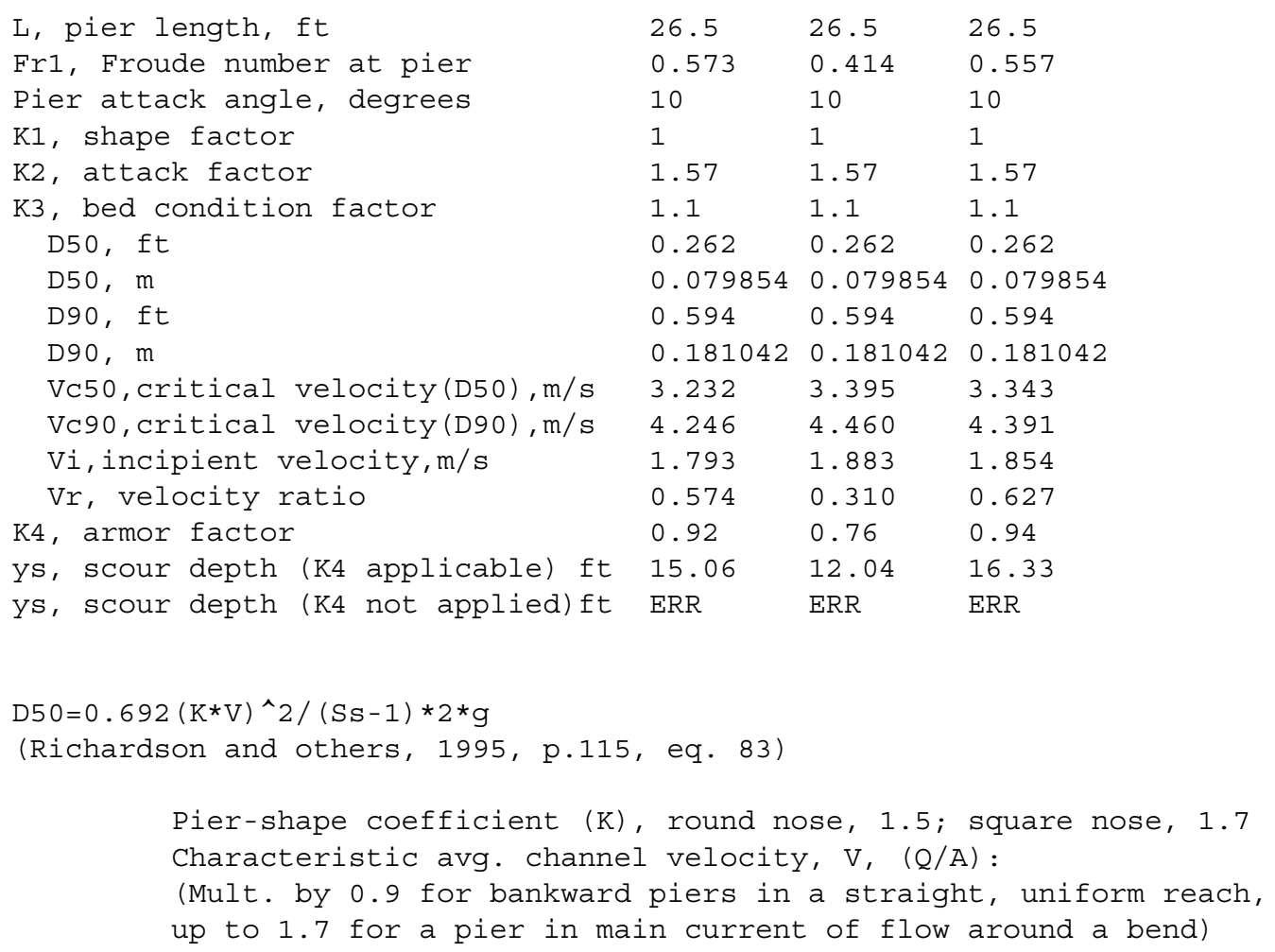

Pier 1

$\mathrm{K}$, pier shape coeff.

$\mathrm{V}$, char. aver. velocity, ft/s

D50, median stone diameter, ft

$\begin{array}{lll}\text { Q100 } & \text { Q500 } & \text { Qother } \\ 1.5 & 1.5 & 1.5 \\ 12.5 & 10.5 & 13.2 \\ 2.29 & 1.62 & 2.55\end{array}$


